\title{
catalysts
}

ISSN 2073-4344

www.mdpi.com/journal/catalysts

Review

\section{Hydrogen Production from Semiconductor-based Photocatalysis via Water Splitting}

Chi-Hung Liao ${ }^{1,2}$, Chao-Wei Huang ${ }^{1,2}$ and Jeffrey C. S. Wu ${ }^{1, *}$

1 Department of Chemical Engineering, National Taiwan University, Taipei 10617, Taiwan;

E-Mails: raymond.liao@iner.gov.tw (C.H.L.); huangcw@iner.gov.tw (C.-W.H.)

2 Institute of Nuclear Energy Research, Atomic Energy Council, Lungtan 32546, Taiwan

* Author to whom correspondence should be addressed; E-Mail: cswu@ntu.edu.tw;

Tel.:+886-2-2363-1994; Fax: +886-2-2362-3040.

Received: 4 July 2012; in revised form: 30 August 2012 / Accepted: 28 September 2012 /

Published: 17 October 2012

\begin{abstract}
Hydrogen is the ideal fuel for the future because it is clean, energy efficient, and abundant in nature. While various technologies can be used to generate hydrogen, only some of them can be considered environmentally friendly. Recently, solar hydrogen generated via photocatalytic water splitting has attracted tremendous attention and has been extensively studied because of its great potential for low-cost and clean hydrogen production. This paper gives a comprehensive review of the development of photocatalytic water splitting for generating hydrogen, particularly under visible-light irradiation. The topics covered include an introduction of hydrogen production technologies, a review of photocatalytic water splitting over titania and non-titania based photocatalysts, a discussion of the types of photocatalytic water-splitting approaches, and a conclusion for the current challenges and future prospects of photocatalytic water splitting. Based on the literatures reported here, the development of highly stable visible-light-active photocatalytic materials, and the design of efficient, low-cost photoreactor systems are the key for the advancement of solar-hydrogen production via photocatalytic water splitting in the future.
\end{abstract}

Keywords: solar-hydrogen; photocatalysis; water splitting; renewable energy 


\section{Alternative Energies and Hydrogen}

Human civilization is built by our energy system, which facilitates the development of technologies that provide us with a higher standard of living. Energy is an essential part of productivity and is as important as raw materials, capital, and labor. Today, most of the energy that we use comes from fossil fuels, which are not considered ideal due to the following reasons: First, the combustion of fossil fuels, such as coal and petroleum, will produce carbon dioxide $\left(\mathrm{CO}_{2}\right)$, which is one of the major greenhouse gases that causes climate change [1]; Second, the amount of fossil fuel on the Earth is limited and will be depleted someday. Nature has stored solar energy in the form of mineral organic compounds or in fossil fuels such as coal, petroleum, and natural gas through millions of years of biological and non-biological processes [2]. However, the rate of global energy consumption has far exceeded the rate of energy storage, implying that fossil fuels will soon be exhausted [3]; Third, fossil fuels are generally controlled by certain nations in the world. As a result, a significant amount of time and money will be spent for the relocation and distribution of these fuels. To satisfy the energy demand, competition for resources among nations will continue to be seen. Therefore, it is imperative for us to search for a sustainable energy source that can be easily produced at low cost and that is friendly to the environment.

To replace or reduce the use of fossil fuels, several alternative energies have been developed. Alternative energies are renewable and have lower carbon emissions when compared to conventional energy sources. These energy sources include wind, hydropower, solar, geothermal, etc. The term "wind energy" describes the process by which the wind is used to generate mechanical power or electricity [4]. Although wind energy is a free, renewable resource, its major challenge is that wind cannot be stored, and not all wind can be harnessed to meet the timing of the demand for electricity.

Hydropower is energy that is generated by water and converted to electricity [5]. The most common method of using energy from water is a hydroelectric dam in which water passes through turbines, causing them to rotate, and then the energy is captured to run a generator. The major disadvantage of hydropower is that dams are extremely expensive to build, which means that they must operate for many decades to become profitable. Moreover, the building of large dams can often cause serious geological and ecological damage.

Solar energy is a free, inexhaustible resource from the sun that can be converted to electricity (photovoltaic power) or heat using devices such as solar cells [6] or concentrators [7]. Electricity produced from solar energy has advantages over wind power and hydropower, since the later two need turbines with moving parts that are both noisy and require much maintenance. However, the major disadvantage of solar energy is its intermittent nature. That is, the amount of sunlight a location receives varies greatly depending on the geographical location, time of day, season, and even clouds.

Geothermal energy is obtained by extracting heat from water or rocks deep underground [8]. Unlike wind and solar energy, geothermal energy is not intermittent, and hence it can be a reliable energy source for several years. However, heat typically is extracted from the rocks much more rapidly than it is restored from the environment. Therefore, geothermal plants have limited lifetimes and require periodic drilling of new holes for continued operation, which in turn increases the cost of electricity. In sum, the availability of energy from renewable sources is unstable with variability in location and time, and the energy may not be available to the end-users when it is needed. Therefore, it is necessary to identify a medium or container in which to store the energy. 
Hydrogen is an ideal energy storage medium or carrier because of the following reasons; First, it is the most abundant element and it exists in both water and biomass; Second, it has a high energy yield $(122 \mathrm{~kJ} / \mathrm{g})$ compared to other fuels such as gasoline $(40 \mathrm{~kJ} / \mathrm{g})$; Third, it is environmentally friendly because its end use will not produce pollutants, greenhouse gases, nor any harmful effect on the environment. Last, but not least, hydrogen can be stored in gaseous, liquid or metal hydride form and can be distributed over large distances through pipelines or via tankers.

\subsection{Some Concerns about Hydrogen}

Despite the above advantages, application of hydrogen technologies may have some limitations. In order to serve as a practical fuel for transportation, hydrogen must be compressed to minimize its storage volume because of its low energy density. Hydrogen with low volumetric energy is generally stored as a compressed gas or liquid, meaning that an advanced compression process is needed. However, such processes will require energy and expansive equipment, which adds costs to the use of hydrogen. The storage of hydrogen in metal hydride form is another alternative to compression. However, metal hydrides are often expensive, heavy, and have a limited lifetime, making the process costly and less practical [9]. Considering the application of hydrogen in road transportation, present efforts are based on two directions. One is to make hydrogen-combustion vehicles, and the other is to make hydrogen fuel-cell vehicles. The advantages of hydrogen vehicles include a reduction in the emission of carbon dioxide and other smog-producing pollutants, as well as a great reduction in the release of nitrogen oxides $\left(\mathrm{NO}_{x}\right)$. Unfortunately, the introduction of hydrogen vehicles into the commercial market has faced the challenges of inadequate hydrogen fueling infrastructure and high production cost in comparison to other petroleum-based vehicles. In fact, these problems are interconnected in the sense that customers will not purchase hydrogen vehicles unless adequate fueling is available, that manufacturers will not produce vehicles that people will not buy, and that fuel providers will not install hydrogen stations for vehicles that do not exist.

\subsection{Hydrogen Production}

Currently, most of the world's hydrogen is produced by a process called "steam reforming" [10]. In this process, methane is widely used as fuel since it has the highest hydrogen-to-carbon ratio among hydrocarbons; hence, the by-products generated are minimized. In general, the steam methane reforming (SMR) process consists of two steps. First is the reformation process in which methane mixed with steam is passed over a catalyst bed at high temperature $\left(700-900{ }^{\circ} \mathrm{C}\right)$ and high pressure $(1.5-3 \mathrm{MPa})$ to form a mixture of hydrogen and carbon monoxide (CO) as shown in Equation 1. The second step is the shift reaction in which $\mathrm{CO}$ from the first step reacts with additional steam to give $\mathrm{CO}_{2}$ and more hydrogen (Equation 2).

$$
\begin{aligned}
& \mathrm{CH}_{4}+\mathrm{H}_{2} \mathrm{O} \rightarrow \mathrm{CO}+3 \mathrm{H}_{2} \\
& \mathrm{CO}+\mathrm{H}_{2} \mathrm{O} \rightarrow \mathrm{CO}_{2}+\mathrm{H}_{2}
\end{aligned}
$$

Another process used for hydrogen generation that involves fossil fuels is coal gasification [11]. In this process, the coal undergoes partial oxidation at high temperature and pressure $(\sim 5 \mathrm{MPa})$ with the help of oxygen and steam to produce a mixture of hydrogen, $\mathrm{CO}, \mathrm{CO}_{2}$, methane and other compounds. 
At temperatures above $1000{ }^{\circ} \mathrm{C}$ and pressures of $1 \mathrm{bar}$, mostly hydrogen and $\mathrm{CO}$ remain. The process can be represented by the following reactions ( 3 and 4 ).

$$
\begin{aligned}
& \mathrm{C}+1 / 2 \mathrm{O}_{2} \rightarrow \mathrm{CO} \\
& \mathrm{C}+\mathrm{H}_{2} \mathrm{O} \rightarrow \mathrm{CO}+\mathrm{H}_{2}
\end{aligned}
$$

Biomass, such as crops, plants, and animal wastes, can also be used to produce hydrogen via thermochemical and biological processes. Pyrolysis [12] and gasification are feasible thermochemical routes for hydrogen production, whereas biophotolysis, biological gas shift reaction, and fermentation are promising biological processes that are under development [13]. In the pyrolysis process, biomass is heated rapidly to a high temperature in the absence of oxygen to produce hydrogen, methane, $\mathrm{CO}, \mathrm{CO}_{2}$, carbon, and other compounds, depending on the nature of the biomass. The temperature used for pyrolysis ranges from 400 to $600{ }^{\circ} \mathrm{C}$, and pressure ranges from 0.1 to $0.5 \mathrm{MPa}$.

There is a general perception that hydrogen is a clean fuel, but this may not be necessarily correct. If hydrogen is produced from natural gas, coal, or biomass, it will use a lot of energy, not to mention the substantial amount of $\mathrm{CO}_{2}$ that will be generated as a by-product. Therefore, the best way of producing hydrogen is to utilize an alternative energy, such as hydropower, wind energy, and solar energy, to carry out the water-splitting reaction. Among these alternative energies, solar energy is the most promising approach since region-related limitations are less rigorous as compared to wind energy and hydropower.

\subsection{Hydrogen Production by Solar Energy}

Hydrogen production via solar water splitting generally can be categorized into 3 types: (1) thermochemical water splitting; (2) photobiological water splitting, and (3) photocatalytic water splitting. The principle of thermochemical water splitting is to use concentrators to collect the heat from sunlight, which typically can reach around $2000{ }^{\circ} \mathrm{C}$, and to utilize the collected heat to perform the water-splitting reaction under the presence of a catalyst such as $\mathrm{ZnO}$ [14]. The reactions are shown in Equations 5 and 6. Even though this technique appears to be unsophisticated, heat management/control and the search for appropriate heat-resisting materials has become the greatest challenge. Furthermore, large-scale solar concentrator systems are essential to achieve the high temperature requirement; therefore, such a technique is often costly.

$$
\begin{gathered}
\mathrm{ZnO}+\text { Heat }\left(\sim 2000^{\circ} \mathrm{C}\right) \rightarrow \mathrm{Zn}+\mathrm{O}_{2} \\
\mathrm{Zn}+\mathrm{H}_{2} \mathrm{O}+\text { Heat }\left(\sim 500^{\circ} \mathrm{C}\right) \rightarrow \mathrm{ZnO}+\mathrm{H}_{2}
\end{gathered}
$$

Photobiological water splitting [15] basically can be divided into two groups based on the microorganisms selected, products generated, and reaction mechanisms involved. Hydrogen production by photosynthetic oxygenic cyanobacteria or green algae under light irradiation and anaerobic condition is referred to as water biophotolysis, while hydrogen production by photosynthetic anoxygenic bacteria under light irradiation and anaerobic condition is referred to as organic biophotolysis.

Although organic biophotolysis is capable of decomposing organic wastes to give a high hydrogen yield, the reactions will generate $\mathrm{CO}_{2}$ as the by-product, which has made the technology less environmentally friendly as compared with water biophotolysis. In water biophotolysis, on the other 
hand, water is transformed into hydrogen and oxygen in the presence of light by cyanobacteria or green algae with the help of a special enzyme such as hydrogenase or nitrogenase, as illustrated in Equations 7 and $8[16,17]$.

$$
\begin{gathered}
\text { Hydrogenase: } 2 \mathrm{H}^{+}+2 \mathrm{e}^{-} \rightarrow \mathrm{H}_{2} \\
\text { Nitrogenase: } \mathrm{N}_{2}+8 \mathrm{H}^{+}+8 \mathrm{e}^{-}+16 \mathrm{ATP} \rightarrow 2 \mathrm{NH}_{3}+\mathrm{H}_{2}+16 \mathrm{ADP}+16 \mathrm{P}_{i}
\end{gathered}
$$

Despite water biophotolysis being a "cleaner" way to produce hydrogen as comparing with organic biophotolysis, it still has many problems waiting to be solved, including low hydrogen yield, the poisoning effect of enzymes under the existence of oxygen (generated simultaneously during biophotolysis), and the difficulty in designing and scaling up the bioreactor for the process.

Photocatalytic water splitting is another promising technology to produce "clean" hydrogen. Compared with thermochemical and photobiological water-splitting techniques, it has the following advantages: (1) reasonable solar-to-hydrogen efficiency; (2) low process cost; (3) the ability to achieve separate hydrogen and oxygen evolution during reaction; and (4) small reactor systems suitable for household applications, thus providing for a huge market potential. The following is an overview of hydrogen generation by photocatalytic water splitting.

\section{Photocatalytic Water Splitting}

Photocatalysis is defined as the chemical reaction induced by photoirradiation in the presence of a catalyst, or more specifically, a photocatalyst. Such material will facilitate chemical reactions without being consumed or transformed. Photosynthesis by plants is a well-known example of photocatalysis in nature, where chlorophyll serves as the photocatalyst. The basic working principle of photocatalysis is simple. First, irradiation of light with energy greater than the bandgap of photocatalyst, separating the vacant conduction band (CB) and filled valence band (VB), excites an electron in VB into CB to result in the formation of an electron $\left(\mathrm{e}^{-}\right)$-hole $\left(\mathrm{h}^{+}\right)$pair. These $\mathrm{e}^{-}$and $\mathrm{h}^{+}$reduce and oxidize respectively chemical species on the surface of photocatalyst, unless they recombine to give no net chemical reaction. The original structure (or chemical composition) of photocatalyst remains unchanged if an equal number of $\mathrm{e}^{-}$and $\mathrm{h}^{+}$are consumed for chemical reaction and/or recombination.

Several terms have been adopted to describe the efficiency for converting solar energy, namely the Applied Bias Photon-to-Current Efficiency (ABPE), and Quantum Efficiency (QE). ABPE is usually used to characterize the photo-response efficiency of a photoelectrode material under an applied voltage. ABPE sometimes is referred to as the photo-conversion efficiency [18]. Due to the voltage applied, such terms cannot be used to represent the true photo-conversion efficiency for photocatalytic water splitting. The definition of photo-conversion efficiency is shown in Equation 9:

$$
\eta_{A B P E}(\%)=\frac{(\text { Total power output }- \text { electrical power input })}{\text { light power input }} \times 100 \%
$$

where $E_{\text {rev }}^{0}$ is $1.23 \mathrm{~V}$, the standard state-reversible potential, $I_{0}$ is the power density of incident light, and $E_{\text {app }}$ is the applied potential. 
As for quantum efficiency, it can represent the characteristic photon conversion of photoactive films. It is defined as the percentage of generated electrons and incident photons while the photoactive films are irradiated under a specific wavelength, as shown in Equation 10 [19].

$$
\eta_{\mathrm{QE}}=\frac{N_{\mathrm{eff}}}{N_{\text {total }}}
$$

In the above equation, $N_{\text {eff }}$ is the number of effective generated electron-hole pairs under light irradiation, and $N_{\text {total }}$ is the total number of incident photons. It is noted that $\eta_{\mathrm{QE}}$ neglects the energy loss of solar irradiance and the chemical conversion efficiency. Therefore, it is suitable to qualify the photoactive films but not to represent the water-splitting reaction conversion efficiency.

To describe the true hydrogen production efficiency of a water-splitting reaction under sunlight, a term called "solar-to-hydrogen" conversion efficiency (STH) [20] is often used. The definition of STH conversion efficiency is shown in Equation 11:

$$
\mathrm{STH}=\left[\frac{\left|j_{\mathrm{sc}}\left(\frac{\mathrm{mA}}{\mathrm{cm}^{2}}\right)\right| \times(1.23 \mathrm{~V}) \times \eta_{\mathrm{F}}}{P_{\text {total }}\left(\frac{m W}{\mathrm{~cm}^{2}}\right)}\right]_{\mathrm{AM} 1.5 \mathrm{G}}
$$

where, $P_{\text {total }}$ represents the power density of incident simulative sunlight (AM1.5G) and the numerator is the product of photocurrent density $\left(j_{\mathrm{sc}}\right)$ at zero bias (short-circuit photocurrent), the thermodynamic voltage required for water splitting $(1.23 \mathrm{~V})$, and the faradic efficiency $\left(\eta_{\mathrm{F}}\right)$. A different form of solar-to-hydrogen conversion efficiency which can also be used is shown in Equation 12:

$$
\mathrm{STH}=\left[\frac{\left(\mathrm{mmole} \mathrm{H}_{2} / \mathrm{s}\right) \times(237 \mathrm{~kJ} / \mathrm{mole})}{\mathrm{P}_{\text {total }}\left(\frac{\mathrm{mW}}{\mathrm{cm}^{2}}\right) \times \operatorname{Area}\left(\mathrm{cm}^{2}\right)}\right]_{\mathrm{AM} 1.5 \mathrm{G}}
$$

where the denominator is the total power of incident simulative sunlight (AM1.5G) multiplied by the area irradiated by the incident light, and the numerator is the product of the $\mathrm{H}_{2}$ evolution rate and the Gibbs free energy for generating one mole of $\mathrm{H}_{2}$ from water.

In a photocatalytic water splitting reaction, photocatalyst plays a crucial role. Until now, titania $\left(\mathrm{TiO}_{2}\right)$ has been a widely used photocatalyst for photocatalytic water splitting because it is stable, non-corrosive, environmentally friendly, abundant, and cost-effective. More importantly, its energy levels are appropriate to initiate the water-splitting reaction [21]. In other words, the $\mathrm{CB}$ of $\mathrm{TiO}_{2}$ is more negative than the reduction energy level of water $\left(E_{\mathrm{H}+/ \mathrm{H} 2}=0 \mathrm{~V}\right)$, while the $\mathrm{VB}$ is more positive than the oxidation energy level of water $\left(E_{\mathrm{O} 2 / \mathrm{H} 2 \mathrm{O}}=+1.23 \mathrm{~V}\right)$, as shown in Figure 1.

Despite the many advantages of $\mathrm{TiO}_{2}$, its photocatalytic water-splitting efficiency under solar energy is still quite low, mainly due to the following reasons; First, the photo-generated electrons in the CB of $\mathrm{TiO}_{2}$ may recombine with the $\mathrm{VB}$ holes quickly to release energy in the form of unproductive heat or photons; Second, the decomposition of water into hydrogen and oxygen is a chemical reaction with large positive Gibbs free energy $(\Delta \mathrm{G}=237 \mathrm{~kJ} / \mathrm{mol}$ ), thus the backward reaction (recombination of hydrogen and oxygen into water) easily proceeds; Third, the bandgap of $\mathrm{TiO}_{2}$ is about $3.2 \mathrm{eV}$, and therefore, only 
UV light can be utilized to activate the photocatalyst. Since UV light only accounts for approximately $4 \%$ of solar energy, while visible light contributes about $50 \%$, the inability to utilize visible light limits the efficiency of $\mathrm{TiO}_{2}$ in solar photocatalytic hydrogen production.

Figure 1. Mechanism of photocatalytic water splitting reproduced ("adapted" or "in part") from ref [21]with permission of The Royal Society of Chemistry.

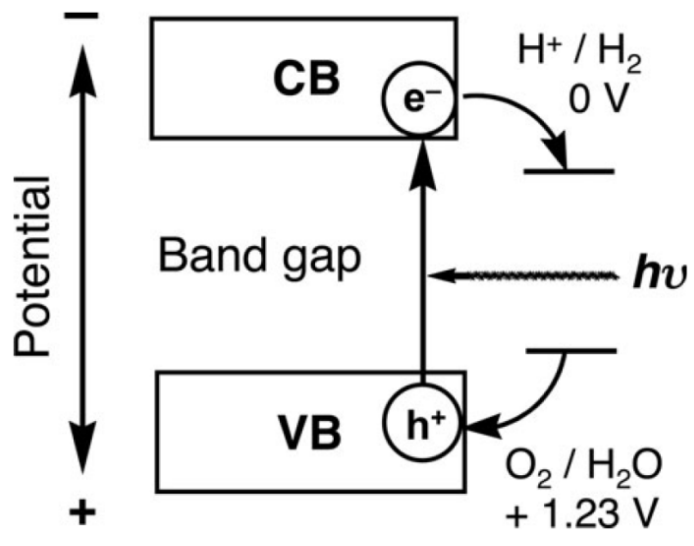

\subsection{How to Improve the Photoactivity of $\mathrm{TiO}_{2}$}

In order to solve the problems mentioned above and to make solar photocatalytic water splitting of $\mathrm{TiO}_{2}$ feasible, continuous efforts have been made to promote the photocatalytic activity of $\mathrm{TiO}_{2}$ and enhance its visible-light response. The techniques that have been investigated in the past include the addition of sacrificial agent/carbonate salts, metal loading, dye sensitization, ion (cation, and anion) doping, etc. Some of them have been proven to be useful for improving the photocatalytic activity of $\mathrm{TiO}_{2}$.

Due to rapid recombination of photo-generated CB electrons and VB holes, it is difficult to achieve water splitting for hydrogen production using $\mathrm{TiO}_{2}$ photocatalyst in pure water. Adding electron donors or sacrificial reagents to react with the photo-generated VB holes is an effective measure to enhance the electron-hole separation, resulting in higher quantum efficiency. However, the drawback of this technique is the need to continuously add electron donors in order to sustain the reaction since they will be consumed during photocatalytic reaction. Li et al. [22] reported enhanced photocatalytic hydrogen production when organic pollutants acting as electron donors, such as oxalic acid, formic acid, and formaldehyde, were added into the reaction system. Decomposition of the organic pollutants was reported to be consistent with hydrogen production. Besides the use of sacrificial agents, the addition of carbonate salts was found to improve photocatalytic hydrogen production by suppressing its backward reaction to form water. Sayama et al. $[23,24]$ reported that adding carbonate salts to Pt-loaded $\mathrm{TiO}_{2}$ suspensions led to highly efficient stoichiometric photocatalytic decomposition of water into $\mathrm{H}_{2}$ and $\mathrm{O}_{2}$. It was found that Pt-loaded $\mathrm{TiO}_{2}$ photocatalyst during reaction was covered with several types of carbonate species. These carbonate species can effectively suppress the back reaction of water splitting to form water and alleviate the photoabsorption of oxygen on the $\mathrm{TiO}_{2}$.

Usually, loading of metals that act as co-catalysts on the surface of photocatalyst, such as $\mathrm{Pt}, \mathrm{Pd}$, or $\mathrm{Rh}$, is essential for enhancing its performance. Loading of metals, including $\mathrm{Pt}, \mathrm{Au}, \mathrm{Pd}, \mathrm{Rh}, \mathrm{Ni}, \mathrm{Cu}$, and 
$\mathrm{Ag}$, have been reported to be very effective for improving $\mathrm{TiO}_{2}$ 's activity in photocatalysis. As the Fermi levels of these metals are lower than the $\mathrm{CB}$ of $\mathrm{TiO}_{2}$ [25], photo-excited electrons can be transferred from the $\mathrm{CB}$ of $\mathrm{TiO}_{2}$ to metal particles deposited on its surface, while photo-generated $\mathrm{VB}$ holes remain on the photocatalyst. Accumulated electrons on metal particles can then be used to carry out a reduction reaction, while holes on the photocatalyst can be used to carry out the oxidation reaction. Therefore, metals with suitable work-function can help prevent electron-hole recombination, leading to higher photocatalytic activity of $\mathrm{TiO}_{2}$. Bamwenda et al. [26] prepared $\mathrm{Au}$ and $\mathrm{Pt}$ loaded $\mathrm{TiO}_{2}$ photocatalysts by deposition precipitation, impregnation, photodeposition, and colloidal mixing methods for hydrogen production. It was found that synthesis methods and metal loadings affect $\mathrm{H}_{2}$ production significantly. Gold and platinum precursors calcined in air at $300{ }^{\circ} \mathrm{C}$ were found to have the highest activity towards $\mathrm{H}_{2}$ generation, followed by a decline in activity with increasing calcinations temperature. The maximum $\mathrm{H}_{2}$ yield observed for $\mathrm{Pt}-\mathrm{TiO}_{2}$ and $\mathrm{Au}-\mathrm{TiO}_{2}$ corresponded to metal loadings of $0.3-1$ and 1-2 wt.\%, respectively. The roles of $\mathrm{Au}$ and $\mathrm{Pt}$ on $\mathrm{TiO}_{2}$ include the trapping of photogenerated electrons, the reduction of protons, and the formation/desorption of hydrogen. Murdoch and co-workers studied the effect of $\mathrm{Au}$ loading and particle size on photocatalytic hydrogen production over $\mathrm{Au} / \mathrm{TiO}_{2}$ nanoparticles [27]. It was concluded that the increase in the hydrogen production rate is simply due to the greater availability of $\mathrm{Au}$ particles at the interface with $\mathrm{TiO}_{2}$, trapping electrons to reduce hydrogen ions into hydrogen molecules. Anpo and Takeuchi [28] employed ESR signals to investigate electron transfer from $\mathrm{TiO}_{2}$ to Pt particles. It was found that $\mathrm{Ti}^{3+}$ signals increased with irradiation time, and the loading of $\mathrm{Pt}$ reduced the amount of $\mathrm{Ti}^{3+}$. This observation indicates the occurrence of electron transfer from $\mathrm{TiO}_{2}$ to Pt particles.

Besides the role of electron traps to improve the photo electron-hole separation, loading of metal, such as Au or Ag, may also promote the activity of photocatalyst by the surface plasmon resonance (SPR) effect. SPR is defined as the collective motions of the conduction electrons induced by light irradiation, which is associated with a considerable enhancement of the electric near-field [29]. The resonance wavelength strongly depends on the size and shape of the nanoparticles, the inter-particle distance, and the dielectric property of the surrounding medium [30,31]. As for $\mathrm{Au}$ loaded $\mathrm{TiO}_{2}$, electrons from the valence band of photocatalyst are excited to the conduction band by UV light irradiation, and then transferred to the gold particles on $\mathrm{TiO}_{2}$. The SPR effect induced by appropriate visible-light irradiation ( $\sim 560 \mathrm{~nm}$ for $\mathrm{Au}$ ) can then boost the energy intensity of the trapped electrons, resulting in enhancement of photocatalytic activity [32]. Kowalska and co-workers have examined a series of $\mathrm{Au} / \mathrm{TiO}_{2}$ samples prepared by photodeposition for the degradation of carboxylic acids. It was observed that the position of the surface plasmon band varies from 520 to $570 \mathrm{~nm}$ depending on the average particle size of the $\mathrm{TiO}_{2}$ support [33]. It was also observed that gold deposition significantly enhanced the activity of photocatalyst due to the surface plasmon resonance effect. Silva et al. reported the investigation of $\mathrm{Au} / \mathrm{TiO}_{2}$ nanoparticles for the generation of hydrogen and oxygen from water [34]. They demonstrated that gold nanoparticles exhibit a dual role as light harvesters, injecting electrons into $\mathrm{TiO}_{2}$ 's conduction band, and also as catalytic sites for gas generation, depending on the excitation light source used. For instance, when using excitation wavelengths corresponding to gold plasmon band, gold nanoparticles will absorb photons and inject electrons to the conduction band of $\mathrm{TiO}_{2}$ to perform water reduction.

Dye sensitization is a widely used technique to utilize visible light for energy conversion. Some dyes having redox property and visible-light sensitivity can be used in solar cells as well as photocatalytic 
systems [35]. Under illumination by visible light, the excited dyes can inject electrons to the CB of photocatalyst to initiate the catalytic reactions as illustrated in Figure 2. Higher photoactivity can be obtained by efficient absorption of visible light and efficient transfer of electrons from excited dyes to the $\mathrm{CB}$ of $\mathrm{TiO}_{2}$. The $\mathrm{CB}$ electrons can then be transferred to the metal particle or co-catalyst (such as $\mathrm{Pt}$ ) loaded on the surface to initiate the reduction reaction. In order to regenerate dyes, redox systems or sacrificial agents, such as $\mathrm{I}^{3-} / \mathrm{I}^{-}$pair and EDTA, can be added to the solution to sustain the reaction cycle. The benefits of adopting dye-sensitized photocatalyst systems include inhibiting charge recombination by improving electron-hole separation, increasing the spectrum response range of photocatalyst (i.e., excitation of wide bandgap photocatalyst by visible light), and changing the selectivity or yield of a particular product [36]. Based on the literature reported in the past, inorganic sensitizers, organic dyes, and coordination metal complexes are very effective photosensitizers that have been studied [37,38]. Among them, photosensitization by organic dyes is the most widely studied method because it is known that the organic dyes have prominent visible light absorption properties and that their structures can be changed by easy and low-cost approaches [39]. In past years, many organic dyes, such as eosin Y, riboflavin, cyanine, cresyl violet, hemicyanine, and merocyanine [40,41], have been tested as photosensitizers. However, the stability of pure organic dyes is a notable problem that should be solved immediately before dye sensitization can be applied for practical uses.

Figure 2. Mechanism of dye-sensitized photocatalytic hydrogen production under visible light irradiation.

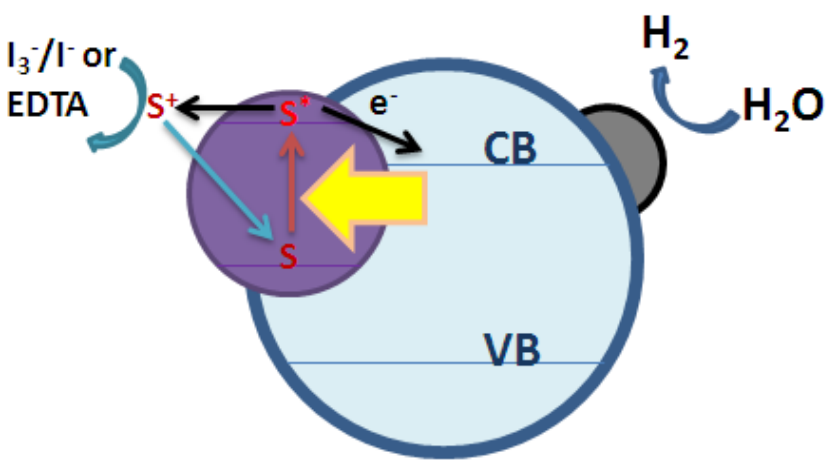

Another common practice for modifying the bandgap of photocatalyst is the so-called metal ion doping practice in which a small percentage of metal ion(s) is incorporated into the crystal lattice of photocatalyst. Transitional metal ion doping and rare-earth metal ion doping have been extensively investigated for enhancing photocatalytic activities of photocatalyst under visible light. Choi et al. [42] carried out a systematic investigation to study the photoactivity of 21 metal ions doped into $\mathrm{TiO}_{2}$. It was found that doping of metal ions could expand the photo-response of $\mathrm{TiO}_{2}$ into visible-light spectrum. As metal ions are incorporated into the $\mathrm{TiO}_{2}$ lattice, impurity energy levels in the bandgap of $\mathrm{TiO}_{2}$ are formed. For photocatalytic reactions, carrier transferring is as important as carrier trapping. Only when the trapped electron and hole are transferred to the surface can photocatalytic reactions occur. Therefore, metal ions should be doped near the surface of photocatalysts for better charge transferring. In the case of deep doping, metal ions are likely to behave as recombination centers, which is unfavorable for the photocatalytic reactions. Among the 21 metal ions studied, Fe, Mo, Ru, Os, Re, V, and Rh ions can 
increase visible light-induced photocatalytic activity, while dopants of $\mathrm{Co}$ and $\mathrm{Al}$ ions cause detrimental effects. The different effects of metal ions result from their abilities to trap and transfer electrons/holes [43].

The use of anion doping to improve photocatalytic activity under visible light is a new method with few investigations reported in the literature. Doping of anions (N, F, C, S etc.) in $\mathrm{TiO}_{2}$ crystalline could shift its photo-response into visible-light spectrum. Unlike metal ions (cations), anions are less likely to form recombination centers and, therefore, are more effective at enhancing photocatalytic activity. Asahi et al. [44] determined the substitutional doping contents of C, N, F, P, and S for O in anatase $\mathrm{TiO}_{2}$. It was found that mixing of $\mathrm{p}$ states of $\mathrm{N}$ with $2 \mathrm{p}$ of $\mathrm{O}$ could shift the VB edge upwards to narrow down the bandgap of $\mathrm{TiO}_{2}$. Although doping of $\mathrm{S}$ had resulted in a similar effect of bandgap narrowing, the ionic radius of $\mathrm{S}$ was reported to be too large to be incorporated into the lattice of $\mathrm{TiO}_{2}$. It was reported by Umebayashi et al. [45] that S-doped $\mathrm{TiO}_{2}$ could be prepared by oxidation annealing of $\mathrm{TiS}_{2}$. Annealed at $600{ }^{\circ} \mathrm{C}, \mathrm{TiS}_{2}$ was partly changed to anatase $\mathrm{TiO}_{2}$. The residual $\mathrm{S}$ atoms in the anatase $\mathrm{TiO}_{2}$ formed S-doped $\mathrm{TiO}_{2}$ by Ti-S bonds. It was found that when $\mathrm{TiO}_{2}$ was doped with $\mathrm{S}$, the mixing of $\mathrm{S} 3 \mathrm{p}$ states with the $\mathrm{VB}$ of $\mathrm{TiO}_{2}$ increased the width of $\mathrm{VB}$, resulting in bandgap narrowing. Since the bandgap narrowing was caused by VB upward shifting, the $\mathrm{CB}$ of the photocatalyst remained unchanged. Therefore, the S-doped $\mathrm{TiO}_{2}$ should be able to reduce protons for hydrogen production under visible light. On the other hand, the upward shift of VB may reduce the oxidation ability under visible light. Also, $\mathrm{N}$-doped $\mathrm{TiO}_{2}$ have been extensively investigated. The reported methods to dope $\mathrm{N}$ are heating of titanium hydroxide and urea, reactive DC magnetron sputtering, nitriding of anatase $\mathrm{TiO}_{2}$ with alkylammonium salts, and treating $\mathrm{TiO}_{2}$ powder in $\mathrm{NH}_{3} / \mathrm{Ar}$ gas flow at $550{ }^{\circ} \mathrm{C}$ [46-48]. Similar to S-doping, N-doping also caused a VB upward shift resulting in a narrowed bandgap. To achieve a highly efficient photocatalytic water-splitting reaction, the coupling of different approaches may sometimes be necessary.

\subsection{High-Efficient Photocatalytic System for Water Splitting}

Even though modified $\mathrm{TiO}_{2}$ has shown improved photocatalytic activity towards water-splitting reaction, its performance is still far below the requirement for commercialization because of the intrinsic limitation of $\mathrm{TiO}_{2}$. As a result, researchers have started to develop other potential photocatalysts to improve the efficiency of water-splitting reaction. Most of the high-efficiency photocatalysts synthesized for $\mathrm{H}_{2}$ production via photocatalytic water splitting are composed of two or more components that are more complicated than $\mathrm{TiO}_{2}$. An example is the $\mathrm{NiO}-\mathrm{SrTiO}_{3}$ photocatalyst prepared by Domen and his group [49]. Nickel oxide (NiO) as a co-catalyst was first loaded on the surface of $\mathrm{SrTiO}_{3}$, which then underwent reduction and oxidation by hydrogen and oxygen, respectively, to form a core (Ni)-shell (NiO) structure, as shown in Figure 3. The co-catalyst with a core-shell structure is believed to facilitate the transport of electrons toward the surface of the photocatalyst, hence improving the photoactivity.

Kudo et al. [50] also prepared NiO-Ni loaded $\mathrm{Sr}_{2} \mathrm{Ta}_{2} \mathrm{O}_{7}$ and $\mathrm{Sr}_{2} \mathrm{Nb}_{2} \mathrm{O}_{7}$ photocatalysts for water splitting reaction. However, the loading of $\mathrm{NiO}-\mathrm{Ni}$ only improved the activity of $\mathrm{Sr}_{2} \mathrm{Nb}_{2} \mathrm{O}_{7}$. A possible reason is that the transfer electrons from the $\mathrm{CB}$ of $\mathrm{Sr}_{2} \mathrm{Ta}_{2} \mathrm{O}_{7}$ to that of $\mathrm{NiO}$, the active site for hydrogen generation, is likely, whereas the transfer of electrons from the $\mathrm{CB}$ of $\mathrm{Sr}_{2} \mathrm{Nb}_{2} \mathrm{O}_{7}$ to that of $\mathrm{NiO}$ is difficult because of their similar CB energy levels, as shown in Figure 4. In addition to that, photocatalytic 
activities of various tantalates for water decomposition were also investigated by Kudo et al. [51]. In the alkali and alkaline earth tantalates, $\mathrm{LiTaO}_{3}, \mathrm{NaTaO}_{3}, \mathrm{KTaO}_{3}, \mathrm{MgTa}_{2} \mathrm{O}_{6}$, and $\mathrm{BaTa}_{2} \mathrm{O}_{6}$ showed photocatalytic activities for water decomposition without co-catalysts. In the transition metal tantalates, on the other hand, $\mathrm{NiTa}_{2} \mathrm{O}_{6}$ produced both $\mathrm{H}_{2}$ and $\mathrm{O}_{2}$ without co-catalysts.

Figure 3. $\mathrm{NiO}-\mathrm{SrTiO}_{3}$ photocatalyst after reduction and oxidation treatments reprinted (adapted) with permission from ref [49]. Copyright (1986) American Chemical Society.

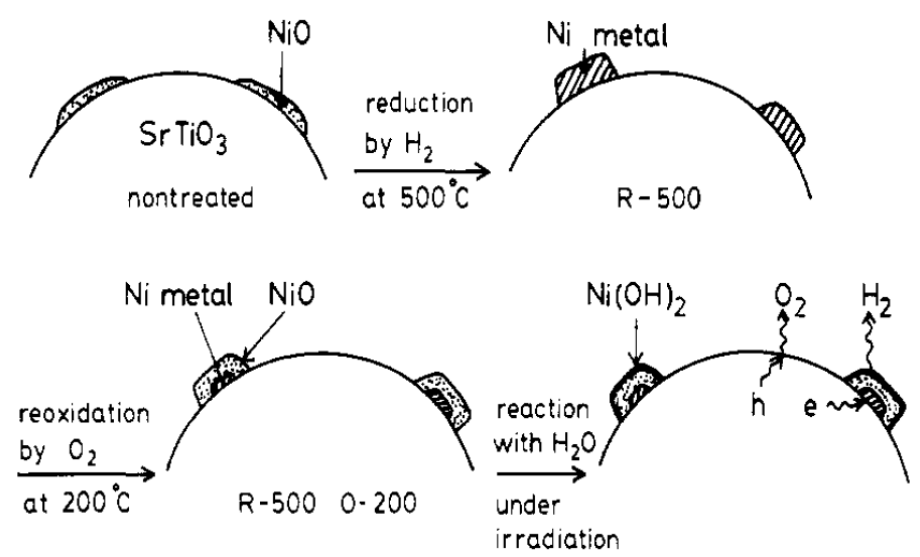

From the above results, it is noteworthy that not only the nature of the photocatalyst is crucial in determining its activity, but the loaded co-catalyst is as well. Sato et al. compared the activity of $\mathrm{CaIn}_{2} \mathrm{O}_{4}$ and $\mathrm{RuO}_{2}$-loaded $\mathrm{CaIn}_{2} \mathrm{O}_{4}$ and concluded that the performance of $\mathrm{CaIn}_{2} \mathrm{O}_{4}$ will be enhanced by loading $\mathrm{RuO}_{2}$. However, excess $\mathrm{RuO}_{2}$ loaded on $\mathrm{CaIn}_{2} \mathrm{O}_{4}$ will cause an adverse effect because of the aggregation of $\mathrm{RuO}_{2}$, which lowers the active surface area of the photocatalyst [52].

Sayama et al. [53] reported the preparation of new layered compounds, $\mathrm{A}_{4} \mathrm{Ta}_{x} \mathrm{Nb}_{6-x} \mathrm{O}_{17}(\mathrm{~A}=\mathrm{K}$ or $\mathrm{Rb}$, $x=2,3,4$ and 6), which had two different kinds of interlayer spaces. It was found that these compounds with intercalated nickel metal particles showed a remarkable photocatalytic activity for water splitting. In the case of $\mathrm{Ni}-\mathrm{K}_{4} \mathrm{Ta}_{\mathrm{x}} \mathrm{Nb}_{6-\mathrm{x}} \mathrm{O}_{17}$, the rate of $\mathrm{H}_{2}$ and $\mathrm{O}_{2}$ evolutions decreased with the increase of $\mathrm{Ta}$ substitution, even though the UV absorption shifted to a longer wavelength, suggesting that the extended absorption to a longer wavelength did not contribute to the photocatalytic water splitting. It was also found that $\mathrm{A}_{4} \mathrm{Ta}_{x} \mathrm{Nb}_{6-x} \mathrm{O}_{17}$ itself without any modification could decompose water, which confirmed that a structure consisting of two different kinds of interlayer spaces is essential for water splitting.

Coupling of non-oxide photocatalyst with oxide or other non-oxide photocatalysts (the so-called composite photocatalyst) is another approach to increase the photocatalytic activity by achieving efficient charge separation and by expanding the absorption spectrum of the photocatalyst at the same time. Examples of composite photocatalyst include $\mathrm{CdS}_{-} \mathrm{TiO}_{2}, \mathrm{CdS}-\mathrm{ZnO}$, and CdS-AgI. Taking $\mathrm{CdS}-\mathrm{TiO}_{2}$ as an example [54], the electrons generated on the $\mathrm{CB}$ of visible-light active $\mathrm{CdS}$ can be transferred to the $\mathrm{CB}$ of $\mathrm{TiO}_{2}$, while holes remain on the VB of CdS as shown in Figure 5. The difference in the energy level of the two photocatalysts plays an important role in achieving such charge separation. Despite the improved activity of composite photocatalysts, most of the narrowed bandgap non-oxide photocatalysts involved may encounter photocorrosion problems in aqueous solution because of their material nature [55], which greatly confines their application in photocatalytic water splitting. 
Figure 4. Band structures of $\mathrm{Sr}_{2} \mathrm{M}_{2} \mathrm{O}_{7}(\mathrm{M}=\mathrm{Nb}$ and $\mathrm{Ta})$ photocatalysts and $\mathrm{NiO}$ co-catalyst Reprinted (adapted) with permission from ref [50]. Copyright (2000) American Chemical Society.

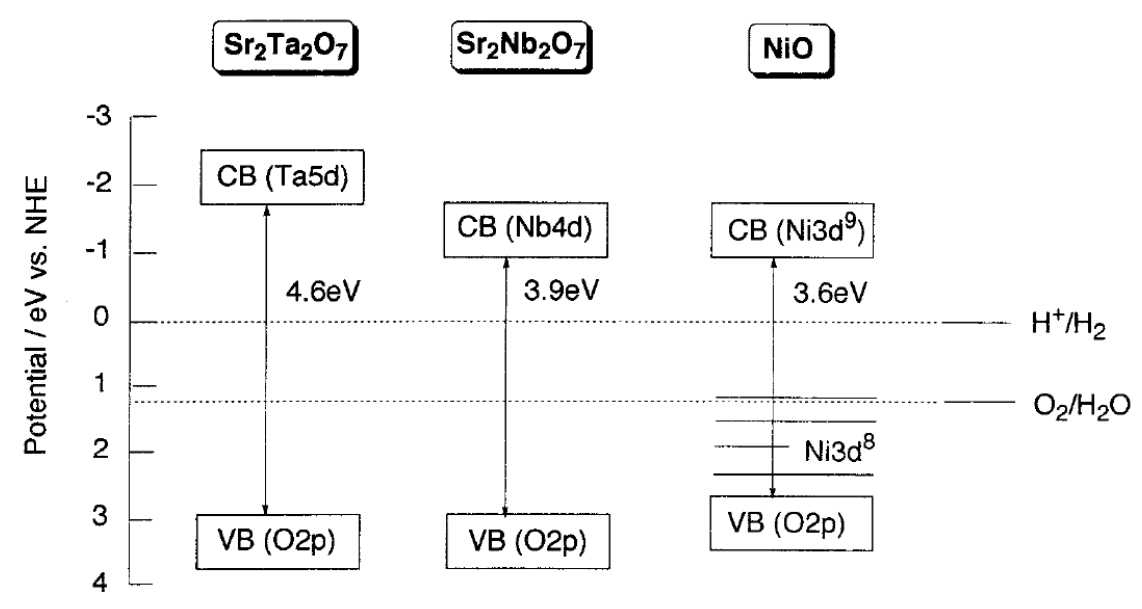

Figure 5. Schematic diagram of the energy levels of $\mathrm{CdS}-\mathrm{TiO}_{2}$ composite photocatalyst Reprinted (adapted) with permission from ref [55]. Copyright (1990) American Chemical Society.

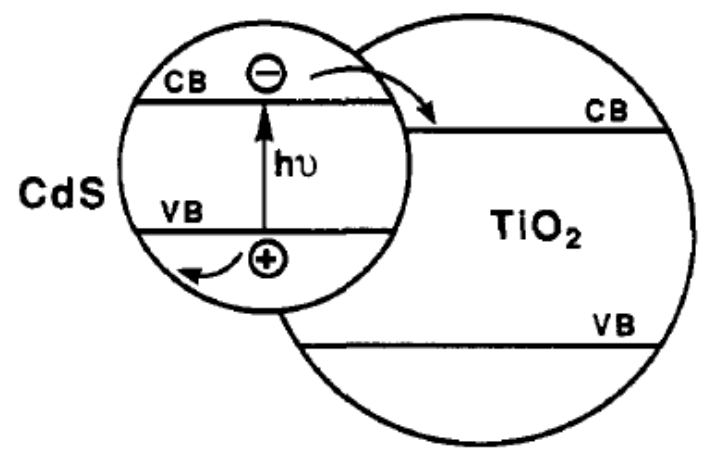

To overcome the photocorrosion problem of composite photocatalyst while maintaining its high efficiency, a photocatalytic system called Z-scheme, which mimics the Z-scheme mechanism in the natural photosynthesis of green plants, has been developed [56] to generate $\mathrm{H}_{2}$ and $\mathrm{O}_{2}$ simultaneously. The Z-scheme is a dual-photocatalyst system that basically consists of a $\mathrm{H}_{2}$-photocatalyst and an $\mathrm{O}_{2}$-photocatalyst to perform water reduction and oxidation, respectively. In addition, a reversible redox mediator, such as $\mathrm{Fe}^{2+} / \mathrm{Fe}^{3+}$, is essential to regenerate the photocatalyst so that un-reacted electrons and holes in $\mathrm{O}_{2}$-photocatalyst and $\mathrm{H}_{2}$-photocatalyst, respectively, can be removed to allow sustained photoreaction. The detailed mechanism of a Z-scheme system is shown in Figure 6. There are some limitations to the redox mediators used for Z-scheme process. First, the redox potential of mediator must be appropriate for the photocatalysts selected. For instance, the oxidation potential of the reducing agent (i.e., $\mathrm{Fe}^{2+}$ ) must be higher than the valence band of $\mathrm{H}_{2}$-photocatalyst, and the reduction potential of oxidizing agent (i.e., $\mathrm{Fe}^{3+}$ ) must be lower than the conduction band of $\mathrm{O}_{2}$-photocatalyst. Second, some redox mediators are only chemically stable under specific $\mathrm{pH}$ condition; for example, $\mathrm{Fe}^{3+}$ will form 
precipitate under basic conditions. Last but not least, some redox mediators, such as $\mathrm{Fe}^{2+} / \mathrm{Fe}^{3+}$ and $\mathrm{I}^{-} / \mathrm{IO}_{3}{ }^{-}$, are light absorbers that will compete with photocatalysts in light absorption.

Figure 6. Mechanism of Z-scheme system for water-splitting reaction reprinted from ref [56], Copyright (2008), with permission from Elsevier.

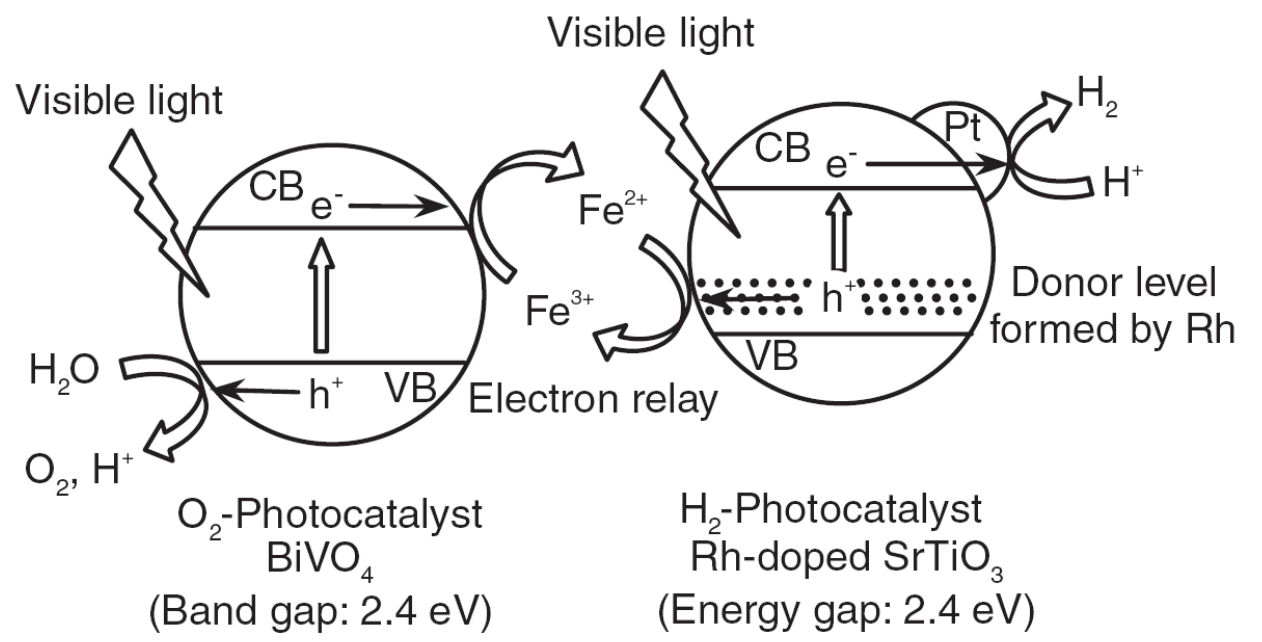

Fujihara and coworkers [57] reported the photocatalytic water splitting using photocatalyst-coated platinum electrodes and a cation-exchange membrane in a two-compartment reactor, where $\mathrm{H}_{2}$ was evolved on $\mathrm{Pt} / \mathrm{TiO}_{2}$ (anatase) photocatalyst suspended in a $\mathrm{Br}_{2} / \mathrm{Br}^{-}$redox mediator solution and $\mathrm{O}_{2}$ was evolved on $\mathrm{Pt} / \mathrm{TiO}_{2}$ (rutile) photocatalyst in a $\mathrm{Fe}^{3+} / \mathrm{Fe}^{2+}$ redox mediator solution. Abe et al. reported the Z-scheme photocatalytic system consisted of $\mathrm{Pt} / \mathrm{TaON}$ as $\mathrm{H}_{2}$-photocatalyst, $\mathrm{Pt} / \mathrm{WO}_{3}$ as $\mathrm{O}_{2}$-photocatalyst, and $\mathrm{I}^{-} / \mathrm{IO}^{3-}$ as the redox mediator to perform water splitting under visible-light irradiation [45]. Sayama et al. also used $\mathrm{I}^{-} / \mathrm{IO}^{3-}$ as the redox mediator to carry out water splitting under visible light, while $\mathrm{Pt} / \mathrm{SrTiO}_{3}: \mathrm{Cr} / \mathrm{Ta}$ and $\mathrm{Pt} / \mathrm{WO}_{3}$ were selected as $\mathrm{H}_{2}$-photocatalyst and $\mathrm{O}_{2}$-photocatalyst, respectively [58]. Higashi et al. reported the Z-scheme system for water-splitting reaction using $\mathrm{ATaO}_{2} \mathrm{~N}(\mathrm{~A}=\mathrm{Ca}, \mathrm{Sr}, \mathrm{Ba})$ as $\mathrm{H}_{2}$-photocatalyst and $\mathrm{WO}_{3}$ as $\mathrm{O}_{2}$-photocatalyst in the $\mathrm{IO}_{3}{ }^{-} / \mathrm{I}^{-}$solution [59]. $\mathrm{ATaO}_{2} \mathrm{~N}$ was prepared by calcining $\mathrm{A}_{2} \mathrm{Ta}_{2} \mathrm{O}_{7}$ in $\mathrm{NH}_{3}$ for $20 \mathrm{~h}$. Among these prepared $\mathrm{H}_{2}$-photocatalysts, $\mathrm{BaTaO}_{2} \mathrm{~N}$ showed the largest absorption spectrum, which extended over the wavelength of $600 \mathrm{~nm}$. The system using $\mathrm{Pt} / \mathrm{BaTaO}_{2} \mathrm{~N}$ and $\mathrm{Pt} / \mathrm{WO}_{3}$ as the $\mathrm{H}_{2}$-photocatalyst and $\mathrm{O}_{2}$-photocatalyst, respectively, in the solution of $5 \mathrm{mM} \mathrm{NaI}$ has demonstrated hydrogen yield of $95 \mu \mathrm{mol}$ in a total reaction time of $50 \mathrm{~h}$. Kato et al. used $\mathrm{Pt} / \mathrm{SrTiO}_{3}: \mathrm{Rh}$ as the $\mathrm{H}_{2}$-photocatalyst and a variety of $\mathrm{O}_{2}$-photocatalysts, such as $\mathrm{BiVO}_{4}, \mathrm{Bi}_{2} \mathrm{MoO}_{6}$, and $\mathrm{WO}_{3}$ in $2 \mathrm{mM} \mathrm{Fe}^{3+}$ solution to conduct the water-splitting reaction under visible-light irradiation [60]. The total amount of hydrogen produced for $\mathrm{BiVO}_{4}$ was $1800 \mu \mathrm{mol}$ in $120 \mathrm{~h}$, and that for $\mathrm{WO}_{3}$ was 1240 $\mu \mathrm{mol}$ in $158 \mathrm{~h}$.

\subsection{Types of Photocatalytic Water-Splitting Reaction}

In general, the literature on hydrogen production via photocatalytic water splitting can be classified into 2 types: (1) photochemical-cell reaction; and (2) photoelectrochemical-cell reaction. In a photochemical cell, powder photocatalyst as suspended particles in solution is used to perform the 
water-splitting reaction. Most of the photocatalytic water-splitting reactions that we have introduced so far are examples of photochemical-cell reaction. In a photoelectrochemical cell, on the other hand, photocatalyst is deposited as a thin film on a substrate to form a photo-anode (or photoelectrode) for carrying out the water-splitting reaction in solution. An external circuit is required to direct the photo-generated electrons from photo-anode to a cathode where hydrogen is evolved. An example of photocatalytic water splitting performed in a photoelectrochemical cell (PEC) was first demonstrated by Fujishima and Honda in 1972 [61]. Figure 7 is a schematic diagram of the photoelectrochemical cell (PEC) used to carry out the reaction. The mechanism basically involves 4 major steps: (1) generation of electron-hole pairs upon light irradiation on the photo-anode; (2) oxidation of water by photo-generated holes on the photo-anode surface to give $\mathrm{O}_{2}$ and $\mathrm{H}^{+}$; (3) transfer of photo-generated electrons through an external circuit to the cathode; and (4) reduction of $\mathrm{H}^{+}$by photo-generated electrons on the cathode surface to give $\mathrm{H}_{2}$.

Figure 7. Schematic diagram of a photoelectrochemical cell.

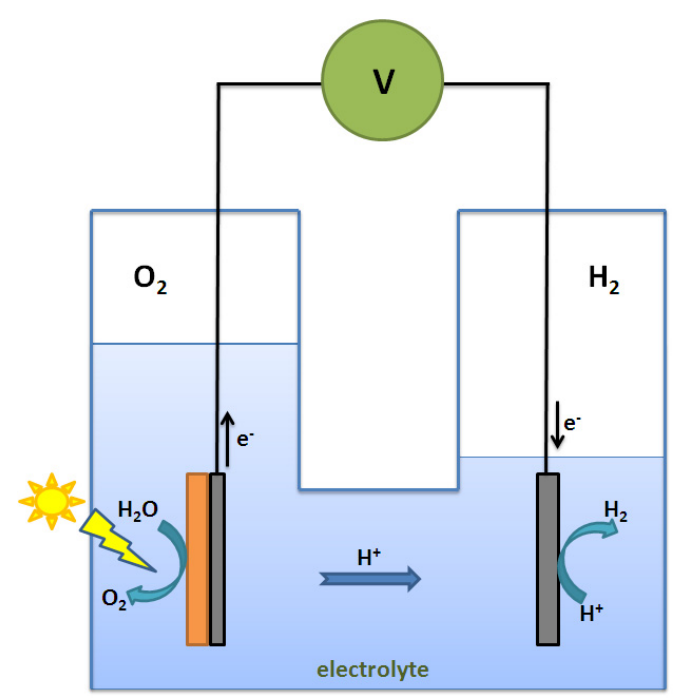

Usually, photochemical cells have the advantage of a simple process because additional film deposition or coating equipment is not required. Another advantage is that suspended photocatalyst tends to have a larger surface area per unit weight available for photocatalytic reaction, which means more active sites for photocatalytic reaction. The advantage of photoelectrochemical cell is that an internal bias can be easily achieved by the photo-anode with a combination of different materials. The bias formed will facilitate electron-hole separation and result in higher photocatalytic activity. Other than the internal bias, an external bias can also be applied between the electrodes for further enhancement. Under standard conditions, water can be reversibly electrolyzed at a potential of $1.23 \mathrm{~V}$. If, however, the maximum open circuit photopotential of a water-splitting system falls short of $1.23 \mathrm{~V}$, an external bias can be provided to increase the reduction potential energy of the electrodes, making the transfer of electrons energetically feasible. Wrighton et al. [62] reported the use of an n-type semiconductor $\mathrm{SrTiO}_{3}$ electrode in a photoelectrochemical cell to convert $\mathrm{H}_{2} \mathrm{O}$ to $\mathrm{H}_{2}$ and $\mathrm{O}_{2}$. The results reported herein show for the first time that the decomposition of $\mathrm{H}_{2} \mathrm{O}$ can be driven photochemically without any external bias. However, when an external potential was applied, photocurrent measured, as well as the hydrogen yield obtained, increased significantly. Photoelectrode 
stability was confirmed by experiments carried out in oxygen-18 labeled $\mathrm{H}_{2} \mathrm{O}$ and by the lack of weight loss in the $\mathrm{SrTiO}_{3}$. Ki et al. [63] also investigated the photo-effects of undoped and $\mathrm{Nb}_{2} \mathrm{O}_{5^{-}}, \mathrm{Sb}_{2} \mathrm{O}_{3^{-}}$, and $\mathrm{V}_{2} \mathrm{O}_{5}$-doped $\mathrm{SrTiO}_{3}$ electrodes. Photoresponses in undoped $\mathrm{SrTiO}_{3}$ electrodes appeared at a wavelength of about $390 \mathrm{~nm}$, and the quantum efficiency was about 3.5\% at a wavelength of $340 \mathrm{~nm}$ for the applied voltage of $0.5 \mathrm{~V}$ vs. $\mathrm{Ag} / \mathrm{AgCl}$. Photocurrents of $\mathrm{Nb}_{2} \mathrm{O}_{5^{-}}, \mathrm{Sb}_{2} \mathrm{O}_{3^{-}}$, and $\mathrm{V}_{2} \mathrm{O}_{5}$-doped $\mathrm{SrTiO}_{3}$ electrodes decreased as the amount of dopant increased.

Since water oxidation $\left(\mathrm{O}_{2}\right.$ evolution) and reduction $\left(\mathrm{H}_{2}\right.$ evolution) in photoelectrochemical cell occurs at different sites (electrodes), simultaneous separation of evolved $\mathrm{O}_{2}$ and $\mathrm{H}_{2}$ is possible, which is the biggest advantage of photoelectrochemical cells. Instantaneous separation of the produced $\mathrm{O}_{2}$ and $\mathrm{H}_{2}$ not only avoids the backward reaction of water splitting to form water again but also saves on the cost for additional hydrogen separation before usage. Moreover, since the mixture of $\mathrm{O}_{2}$ and $\mathrm{H}_{2}$ is easily combustible, instantaneous separation makes the entire system safe for commercial operation and scale-up. An example that best demonstrates the merits of photoelectrochemical cells is the H-type reactor system proposed by Anpo et al. [64]. The reactor system consisted of an H-type reactor, a photoelectrode, and a Nafion or proton-exchange membrane. Water solution inside the reactor was separated by the photoelectrode and proton-exchange membrane into two compartments as shown in Figure 8 . The photoelectrode was made up of a Ti foil substrate sandwiched by a visible light-active $\mathrm{TiO}_{2}$ photocatalyst anode and a Pt cathode, both of which were prepared by sputtering. The metal Ti foil provides the channel for electron transfer so that the external circuit can be eliminated and electrical resistance can be significantly reduced. Upon light irradiation, water oxidation occurred on $\mathrm{TiO}_{2}$ to give oxygen gas and protons, which then were transferred to the Pt side via proton exchange membrane, while reduction of hydrogen ion occurred on Pt to give hydrogen gas. As a result, separate evolution of $\mathrm{H}_{2}$ and $\mathrm{O}_{2}$ can be achieved.

Figure 8. H-type reaction system for photocatalytic water splitting Reprinted from ref [64], Copyright (2007), with permission from Elsevier.

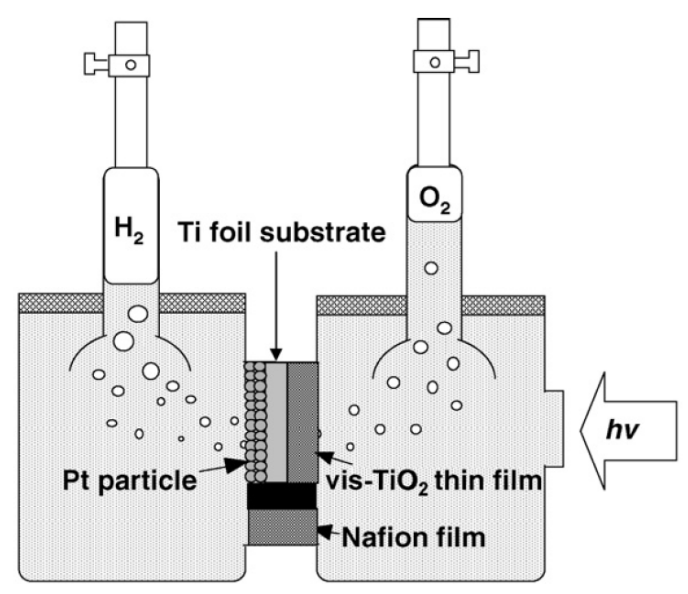

In collaboration with Anpo's group, Wu and his group adopted a similar system to carry out water-splitting reaction in which the visible-light $\mathrm{TiO}_{2}$ of the photoelectrode was prepared by a different physical deposition technique called "electron beam-induced deposition" [65]. Later, a novel dual-layer photoelectrode, which consisted of a layer of visible-light $\mathrm{WO}_{3}$, and a layer of visible-light $\mathrm{TiO}_{2}$ 
deposited on a Pt coated Ti foil was developed by Wu et al. [66]. The dual-layer photoelectrode has the advantages of improved light absorption efficiency in the visible region and better charge separation. The activity of the prepared dual-layer photoelectrode under both UV and visible-light irradiations were evaluated by conducting photovoltammetry and water-splitting reaction in an H-type reactor. The dual-layer photoelectrode showed enhanced photocurrent comparing with $\mathrm{TiO}_{2}$-only photoelectrode, which has been proved to result mainly from the improved charge separation of the dual-layer structure. Moreover, the $\mathrm{H}_{2}$ and $\mathrm{O}_{2}$ yields obtained from the water-splitting reactions were consistent with the photocurrent results, showing dual-layer photoelectrodes with the highest photoactivity. Besides the physical methods such as sputtering and electron beam-induced deposition, a chemical deposition method called "evaporation-induced self-assembling" (EISA) process was also adopted by Wu et al. to prepare mesoporous $\mathrm{TiO}_{2}$ thin films (MTTFs) for fabricating the photoelectrode [67]. In general, the efficiency of photocatalyst strongly depends on its surface area. Therefore, it is important to prepare porous $\mathrm{TiO}_{2}$ thin film with high surface area for carrying out water-splitting reaction. In this study, mesoporous $\mathrm{TiO}_{2}$ thin films with pillar and tube structures were synthesized and characterized (Figure 9). The difference in structure has been revealed to affect not only the translation efficiency of excited electrons, but also influence the interfacial barrier and concentration gradient of the reaction solution. Even though the yield of hydrogen produced in this study was lower than that reported by Anpo et al. [68], it has been demonstrated that mesoporous titania thin films can be successfully prepared by a simple and reliable chemical method instead of an expensive physical method.

Figure 9. SEM image of (a) pillar-MTTFs, and (b) tube-MTTFs Reprinted from ref [67], Copyright (2012), with permission from Elsevier.
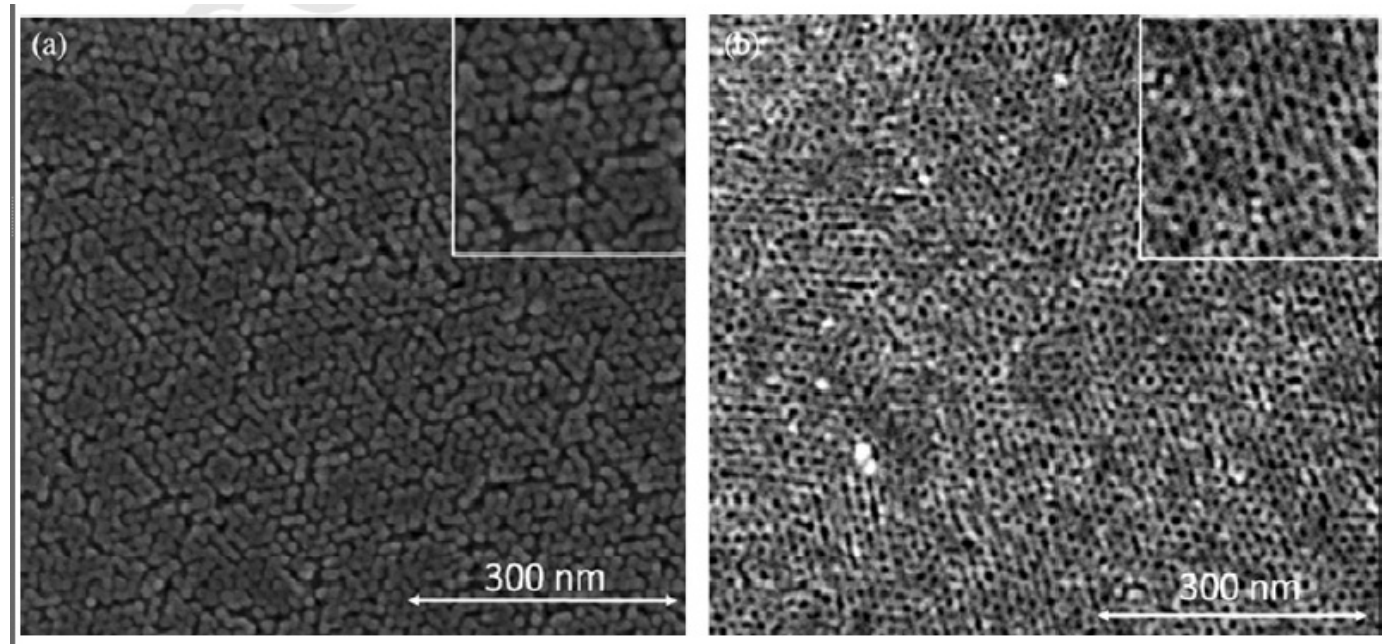

In addition to the H-type reactor system, $\mathrm{Wu}$ and his group has recently developed a novel twin-reactor system that combines the advantages of both Z-scheme and H-type reactor systems to carry out water-splitting reaction [69]. In this novel system, $\mathrm{Pt} / \mathrm{SrTiO}_{3}: \mathrm{Rh}$ and $\mathrm{WO}_{3}$, used as $\mathrm{H}_{2}$-photocatalyst and $\mathrm{O}_{2}$-photocatalyst, respectively, were discretely placed into the compartments of a connected twin reactor separated by a modified ion-exchange membrane, as shown in Figure 10. This modified ion-exchange membrane not only allows the transport of protons, but also the exchange of the mediator ions $\left(\mathrm{Fe}^{2+} / \mathrm{Fe}^{3+}\right)$ in solution. The major merit of this novel system is that separate hydrogen and oxygen evolution can be achieved while using only powder photocatalysts to perform the water-splitting 
reaction. In a subsequent study, $\mathrm{Pt} / \mathrm{SrTiO}_{3}: \mathrm{Rh}$ and $\mathrm{BiVO}_{4}$ were used as the $\mathrm{H}_{2}$-photocatalyst and the $\mathrm{O}_{2}$-photocatalyst, respectively, to run water-splitting reaction in the novel twin-reactor system. The transport phenomenon of iron mediators through modified Nafion membrane was investigated in detail [70]. The apparent diffusivities of the mediator ions, $\mathrm{Fe}^{3+}$ and $\mathrm{Fe}^{2+}$, were derived quantitatively by colorimetric method. By comparing the rate of hydrogen generation with the rate of diffusion for the mediator ions, it was concluded that the resistance of the modified Nafion membrane in the novel twin reactor would not hinder photocatalytic water-splitting reaction. Furthermore, the $\mathrm{H}_{2}$-generating side of the novel twin-reactor system was found to be the rate-limiting step for the water-splitting reaction. It was also concluded in the study that by using the novel twin reactor system, the deactivation of $\mathrm{Pt} / \mathrm{SrTiO}_{3}: \mathrm{Rh}$ often occurring in the conventional Z-scheme system can be successfully minimized by suppressing the formation of $\mathrm{Fe}(\mathrm{OH})_{3}$ on the photocatalyst surface.

Figure 10. Concept of a novel twin-reactor system.

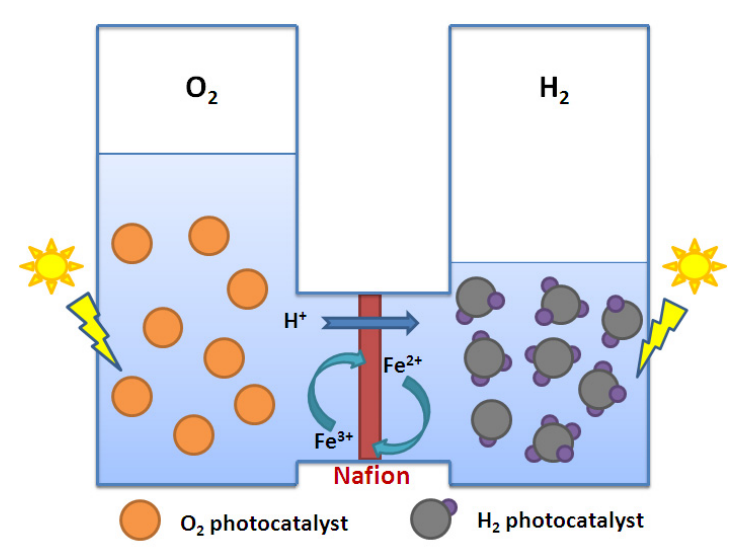

Besides the photoelectrodes made from oxide-based material, semiconductor materials, or particularly, III-V semiconductors have also been used to prepare the high-efficient photoelectrode for water-splitting reaction. Prasad et al. [71] reported a photoanode that corresponds to the $\mathrm{MX}_{2}$ type layered material, $\mathrm{WSe}_{2}$. The $\mathrm{WSe}_{2}$ crystals were grown by the chemical vapor deposition technique with $\mathrm{SeCI}_{4}$ as the transporter. The photoelectrochemical efficiency (light-to-electricity conversion efficiency) of the as grown $n-\mathrm{WSe}_{2}$ crystals was approximately $17 \%$ after a photo-etching treatment was conducted on the crystal surface of $\mathrm{WSe}_{2}$. Licht et al. prepared the dual-junction semiconductor photoelectrode by a process called MOCVD (metal organic chemical vapor deposition). Such photoelectrode, comprised of AlGaAs and Si, can achieve higher conversion efficiency as compared with other single-junction semiconductor materials [72]. A monolithic photovoltaic-photoelectrochemical device for hydrogen production via water splitting was proposed by Khaselev et al. [73]. This photoelectrochemical cell, which was voltage-biased with an integrated photovoltaic device, could split water directly upon illumination (Figure 11). The hydrogen production efficiency of this system, based on the short-circuit current, was around $12.4 \%$. Peharz et al. combined III-V solar cells and polymer electrolyte in an optical concentrator to achieve a photo-conversion efficiency of $18 \%$ [74]. Khaselev et al. prepared $\mathrm{GaInP}_{2} / \mathrm{GaAs}$ photoelectrode with photo-conversion efficiency of $12.4 \%$ under AM1.5 light irradiation [75]. Miller et al. proposed a photoelectrode (Figure 12), which is made up of a multi-junction solar cell and various photocatalysts, such as $\mathrm{Fe}_{2} \mathrm{O}_{3}, \mathrm{WO}_{3}, \mathrm{TiO}_{2}$ [76]. The hybrid planar photoelectrode was designed 
to absorb most of the sunlight to give better photocatalytic performance. The stability of photoelectrode was also improved by using encapsulant, which is transparent and anticorrosive to the electrolyte solution. A cell containing $\mathrm{AlGaAs} / \mathrm{Si} \mathrm{RuO}_{2} / \mathrm{Pt}_{\text {black }}$ was prepared by Licht et al. [77] for water splitting reaction. Under visible-light illumination, the bipolar configured $\mathrm{Al}_{0.15} \mathrm{Ga}_{0.85} \mathrm{As}\left(E_{\mathrm{g}}=1.6 \mathrm{eV}\right)$ and $\mathrm{Si}$ $\left(E_{\mathrm{g}}=1.1 \mathrm{eV}\right)$ semiconductors generate open circuit and maximum power photopotentials of 1.30 and $1.57 \mathrm{~V}$, respectively, well-suited to the water electrolysis thermodynamic potential of $1.23 \mathrm{~V}$. The cell was then combined with an effective water electrolysis catalyst, $\mathrm{RuO}_{2}$, and achieved a photo-conversion efficiency of $18.3 \%$.

Figure 11. Schematic of the monolithic PEC/PV device Reproduced with permission from ref [73]; published by (The American Association for the Advancement of Science), (1998).

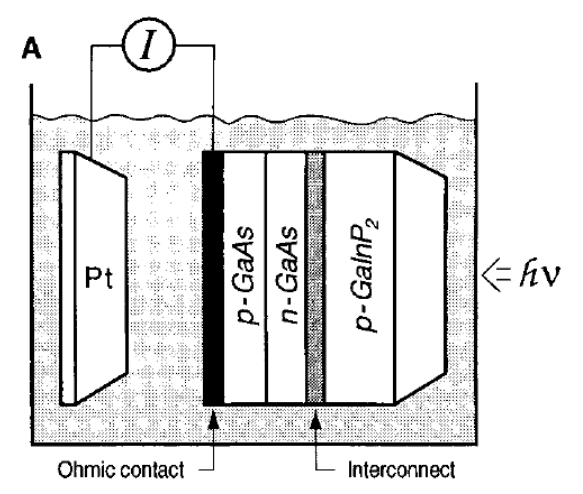

Figure 12. Structure of the hybrid planar photoelectrode (photoactive semiconductor/ITO/solid-state multi-junction/ stainless steel/HER catalyst) for water splitting.

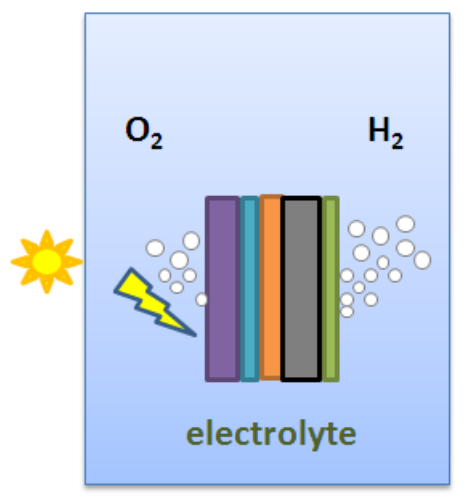

Although many studies have reported the fabrication of high-efficiency multi-junction solar cells for water-splitting reaction, most of the hydrogen yields obtained for these devices were based on the photocurrent generated under light irradiation. So far, none of them has presented the hydrogen yield obtained from the actual water-splitting reaction. Recently, Wu et al. applied a multi-junction solar cell (MJSC) that contains InGaP, GaAs, and Ge sub-cells to the H-type reactor system for carrying out water-splitting reaction [78]. Despite the observed corrosion phenomenon of the Ge bottom cell after photoreaction, a huge hydrogen yield of $440 \mu \mathrm{mol}$ was observed under $8 \mathrm{~h}$ of visible-light irradiation 
(AM 1.5). Furthermore, by replacing the electrolyte solution of $\mathrm{H}_{2} \mathrm{SO}_{4} / \mathrm{NaOH}$ with $\mathrm{Na}_{2} \mathrm{SO}_{4}$, the corrosion phenomenon of the bottom cell was effectively suppressed.

\subsection{Summary of Photocatalytic Water Splitting}

In this section, a summary of the results reported from previous literature is presented. Tables 1 and 2 show the results of several water-splitting reactions carried out in photochemical and photoelectrochemical cell, respectively, over various photocatalytic materials. The conditions at which the reactions were conducted are listed in the Table as well.

Table 1. Water splitting by photochemical-cell reaction over various photocatalysts.

\begin{tabular}{|c|c|c|c|c|c|c|}
\hline \multirow[t]{2}{*}{ Photocatalyst } & \multirow[t]{2}{*}{ Weight } & \multirow{2}{*}{$\begin{array}{l}\text { Reaction } \\
\text { solution }\end{array}$} & \multirow[t]{2}{*}{ Light source } & \multicolumn{2}{|c|}{$\begin{array}{l}\text { Rate of evolution } \\
\left.\qquad(\mu \mathrm{mol} \mathrm{h})^{-1}\right)\end{array}$} & \multirow[t]{2}{*}{ Reference } \\
\hline & & & & $\mathbf{H}_{2}$ & $\mathbf{O}_{2}$ & \\
\hline $\mathrm{Pt} / \mathrm{TiO}_{2}$ & $0.3 \mathrm{~g}$ & $2.17 \mathrm{M} \mathrm{Na}_{2} \mathrm{CO}_{3}$ & $400 \mathrm{~W}$ Hg lamp & 568 & 287 & {$[23]$} \\
\hline $\mathrm{ZrO}_{2}$ & $1 \mathrm{~g}$ & distilled water & 400 W Hg lamp & 72 & 36 & [24] \\
\hline $\mathrm{ZrO}_{2}$ & $1 \mathrm{~g}$ & $1.09 \mathrm{M} \mathrm{Na}_{2} \mathrm{CO}_{3}$ & 400 W Hg lamp & 142 & 75 & {$[24]$} \\
\hline $\mathrm{Pt} / \mathrm{ZrO}_{2}$ & $1 \mathrm{~g}$ & $0.94 \mathrm{M} \mathrm{NaHCO}_{3}$ & 400 W Hg lamp & 120 & 61 & {$[24]$} \\
\hline $\mathrm{Ru}_{2} \mathrm{O} / \mathrm{ZrO}_{2}$ & $1 \mathrm{~g}$ & distilled water & 400 W Hg lamp & 11 & 5 & {$[24]$} \\
\hline $\mathrm{Cu} / \mathrm{ZrO}_{2}$ & $1 \mathrm{~g}$ & distilled water & $400 \mathrm{~W}$ Hg lamp & 14 & 6 & {$[24]$} \\
\hline $\mathrm{NiO} / \mathrm{Sr}_{2} \mathrm{Nb}_{2} \mathrm{O}_{7}$ & $1 \mathrm{~g}$ & distilled water & $400 \mathrm{~W}$ Hg lamp & 110 & 36 & {$[50]$} \\
\hline $\mathrm{NiO} / \mathrm{Sr}_{2} \mathrm{Ta}_{2} \mathrm{O}_{7}$ & $1 \mathrm{~g}$ & distilled water & 400 W Hg lamp & 1000 & 480 & {$[50]$} \\
\hline (Tetra) $\mathrm{BaTa}_{2} \mathrm{O}_{6}$ & $1 \mathrm{~g}$ & distilled water & 400 W Hg lamp & 21 & 10 & {$[51]$} \\
\hline $\begin{array}{c}\text { (Ortho)BaTa2 } \\
\text { O6 } \\
\end{array}$ & $1 \mathrm{~g}$ & distilled water & 400 W Hg lamp & 33 & 15 & {$[51]$} \\
\hline $\begin{array}{c}\text { (Ortho) } \mathrm{BaTa}_{2} \mathrm{O} \\
6 \\
\end{array}$ & $1 \mathrm{~g}$ & $\begin{array}{l}0.0005 \mathrm{M} \\
\mathrm{Ba}(\mathrm{OH})_{2}\end{array}$ & 400 W Hg lamp & 126 & 59 & {$[51]$} \\
\hline $\begin{array}{c}\text { (Ortho) } \mathrm{BaTa}_{2} \mathrm{O} \\
6 \\
\end{array}$ & $1 \mathrm{~g}$ & $0.001 \mathrm{M} \mathrm{KOH}$ & 400 W Hg lamp & 24 & 11 & {$[51]$} \\
\hline $\begin{array}{c}\text { (Ortho) } \mathrm{BaTa}_{2} \mathrm{O} \\
6 \\
\end{array}$ & $1 \mathrm{~g}$ & $0.0005 \mathrm{M} \mathrm{BaCl}_{2}$ & 400 W Hg lamp & 15 & 6 & {$[51]$} \\
\hline $\mathrm{NiO} / \mathrm{BaTa}_{2} \mathrm{O}_{6}$ & $1 \mathrm{~g}$ & distilled water & 400 W Hg lamp & 629 & 303 & {$[51]$} \\
\hline $\mathrm{Ni} / \mathrm{Rb}_{4} \mathrm{Nb}_{6} \mathrm{O}_{17}$ & $1 \mathrm{~g}$ & distilled water & 400 W Hg lamp & 936 & 451 & {$[53]$} \\
\hline $\mathrm{Ni} / \mathrm{K}_{4} \mathrm{Nb}_{6} \mathrm{O}_{17}$ & $1 \mathrm{~g}$ & distilled water & 400 W Hg lamp & 403 & 197 & {$[53]$} \\
\hline $\begin{array}{c}\mathrm{Pt} / \mathrm{TiO}_{2} \\
\mathrm{TiO}_{2} \\
\end{array}$ & $12 \mathrm{mg}$ & $\begin{array}{c}2 \mathrm{M} \mathrm{KBr} \\
6.5 \mathrm{mM} \mathrm{FeCl}_{2}\end{array}$ & $500 \mathrm{~W} \mathrm{Hg}$ & 2.8 & 1.3 & {$[57]$} \\
\hline $\begin{array}{l}\mathrm{Pt}-\mathrm{TaON} \\
\mathrm{Pt}-\mathrm{WO}_{3} \\
\end{array}$ & $0.2 \mathrm{~g}$ & $5 \mathrm{mM} \mathrm{NaI}$ & $\begin{array}{l}300 \mathrm{~W} \text { Xe lamp with } \\
\text { filters: } \lambda>420 \mathrm{~nm}\end{array}$ & 24 & 12 & [45] \\
\hline $\begin{array}{c}\mathrm{Pt} / \mathrm{BaTaO}_{2} \mathrm{~N} \\
\mathrm{Pt} / \mathrm{WO}_{3} \\
\end{array}$ & $0.1 \mathrm{~g}$ & $5 \mathrm{mM} \mathrm{NaI}$ & $\begin{array}{l}300 \mathrm{~W} \text { Xe lamp with } \\
\text { filters: } \lambda>420 \mathrm{~nm}\end{array}$ & 6.6 & 3.1 & [59] \\
\hline $\begin{array}{c}\mathrm{Pt} / \mathrm{SrTiO}_{3}: \mathrm{Rh}, \\
\mathrm{BiVO}_{4}\end{array}$ & $0.1 \mathrm{~g}$ & $2 \mathrm{mM} \mathrm{FeCl}_{3}$ & $\begin{array}{c}\text { 300W Xe with filter: } \\
\qquad \lambda>420 \mathrm{~nm}\end{array}$ & 15 & 7.2 & {$[60]$} \\
\hline $\begin{array}{c}\mathrm{Pt} / \mathrm{SrTiO}_{3}: \mathrm{Rh}, \\
\mathrm{Bi}_{2} \mathrm{MoO}_{6}\end{array}$ & $0.1 \mathrm{~g}$ & $2 \mathrm{mM} \mathrm{FeCl}_{3}$ & $\begin{array}{c}300 \mathrm{~W} \text { Xe with filter: } \\
\quad \lambda>420 \mathrm{~nm}\end{array}$ & 19 & 8.9 & {$[60]$} \\
\hline
\end{tabular}


Table 1. Cont.

\begin{tabular}{|c|c|c|c|c|c|c|}
\hline \multirow{2}{*}{$\begin{array}{l}\text { Photocatalyst } \\
\mathrm{Pt} / \mathrm{SrTiO}_{3}: \mathrm{Rh}, \\
\mathrm{WO}_{3} \\
\end{array}$} & \multirow{2}{*}{$\begin{array}{c}\text { Weight } \\
0.1 \mathrm{~g}\end{array}$} & \multirow{2}{*}{$\begin{array}{c}\begin{array}{c}\text { Reaction } \\
\text { solution }\end{array} \\
2 \mathrm{mM} \mathrm{FeCl}_{3}\end{array}$} & \multirow{2}{*}{$\begin{array}{c}\text { Light source } \\
300 \mathrm{~W} \text { Xe with filter: } \\
\lambda>420 \mathrm{~nm} \\
\end{array}$} & \multicolumn{2}{|c|}{$\begin{array}{l}\text { Rate of evolution } \\
\qquad\left(\mu \mathrm{mol} \mathrm{h} \mathbf{h}^{-1}\right)\end{array}$} & \multirow{2}{*}{$\begin{array}{c}\text { Reference } \\
{[60]}\end{array}$} \\
\hline & & & & 7.8 & 4.0 & \\
\hline $\mathrm{K}_{4} \mathrm{Nb}_{6} \mathrm{O}_{17}$ & $1 \mathrm{~g}$ & $\mathrm{H}_{2} \mathrm{O}$ & 450 W Hg lamp & 8 & 1 & {$[64]$} \\
\hline $\mathrm{NiO} / \mathrm{K}_{4} \mathrm{Nb}_{6} \mathrm{O}_{17}$ & $1 \mathrm{~g}$ & $\mathrm{H}_{2} \mathrm{O}$ & $450 \mathrm{~W}$ Hg lamp & 77 & 37 & {$[64]$} \\
\hline $\begin{array}{c}\mathrm{Pt} / \mathrm{SrTiO}_{3}: \mathrm{Rh} \\
\mathrm{WO}_{3} \\
\end{array}$ & 0.3 & $\begin{array}{c}2 \mathrm{mM} \\
\mathrm{FeCl}_{2} / \mathrm{FeCl}_{3} \\
\end{array}$ & $500 \mathrm{~W}$ halogen lamp & 1.6 & 0.8 & [69] \\
\hline $\begin{array}{c}\mathrm{Pt} / \mathrm{SrTiO}_{3}: \mathrm{Rh} \\
\mathrm{BiVO}_{4}\end{array}$ & 0.4 & $\begin{array}{c}5 \mathrm{mM} \\
\mathrm{FeCl}_{2} / \mathrm{FeCl}_{3}\end{array}$ & 300 W Xe lamp & 0.8 & 0.4 & {$[70]$} \\
\hline
\end{tabular}

Table 2. Water splitting by photoelectrochemical-cell reaction over various photoelectrodes.

\begin{tabular}{|c|c|c|c|c|c|c|}
\hline Photoelectrode & $\begin{array}{c}\text { Surface } \\
\text { area }\left(\mathrm{cm}^{2}\right) \\
\end{array}$ & Electrolyte & Light source & $\begin{array}{c}\text { Efficiency/ } \\
\mathrm{H}_{2} \text { yield }\end{array}$ & $\begin{array}{l}\text { Applied } \\
\text { bias (V) } \\
\end{array}$ & Reference \\
\hline $\mathrm{TiO}_{2}$ & 1 & $\mathrm{Fe}^{3+}$ solution & $\begin{array}{c}500 \text { W Xenon } \\
\text { lamp }\end{array}$ & $\mathrm{QE}=10 \%$ & N/A & {$[61]$} \\
\hline $\mathrm{SrTiO}_{3}$ & 0.25 & $9.5 \mathrm{M} \mathrm{NaOH}$ & $\begin{array}{c}\text { Argon ion laser } \\
(351 \mathrm{~nm})\end{array}$ & $\mathrm{QE}=11 \%$ & N/A & {$[62]$} \\
\hline $\mathrm{SrTiO}_{3}$ & 1.539 & $1 \mathrm{M} \mathrm{NaOH}$ & $\begin{array}{l}150 \mathrm{~W} \text { halogen } \\
\text { lamp }(340 \mathrm{~nm})\end{array}$ & $\mathrm{QE}=3.5 \%$ & 0.5 & {$[63]$} \\
\hline $\mathrm{TiO}_{2}$ & 2 & $\begin{array}{c}0.5 \mathrm{M} \mathrm{H}_{2} \mathrm{SO}_{4} / \\
1 \mathrm{M} \mathrm{NaOH}\end{array}$ & $\begin{array}{c}\text { UV light with } \\
\text { intensity of } 25 \\
\mathrm{~mW} / \mathrm{cm}^{2}\end{array}$ & $\begin{array}{c}60 \mu \mathrm{mol} \text { in } \\
8 \mathrm{~h}\end{array}$ & N/A & {$[65]$} \\
\hline $\begin{array}{l}\text { Vis- } \mathrm{WO}_{3} / \\
\text { vis- } \mathrm{TiO}_{2}\end{array}$ & 2 & $\begin{array}{c}0.025 \mathrm{M} \\
\mathrm{H}_{2} \mathrm{SO}_{4} / \\
0.05 \mathrm{M} \mathrm{NaOH} \\
\end{array}$ & $\begin{array}{c}\text { UV light with } \\
\text { intensity of } 2.5 \\
\mathrm{~mW} / \mathrm{cm}^{2}\end{array}$ & $\begin{array}{c}39 \mu \mathrm{mol} \text { in } \\
8 \mathrm{~h}\end{array}$ & N/A & {$[66]$} \\
\hline $\begin{array}{l}\text { Vis- } \mathrm{WO}_{3} / \\
\text { vis- } \mathrm{TiO}_{2}\end{array}$ & 2 & $\begin{array}{c}0.025 \mathrm{M} \\
\mathrm{H}_{2} \mathrm{SO}_{4} / \\
0.05 \mathrm{M} \mathrm{NaOH}^{2}\end{array}$ & AM 1.5 & $\begin{array}{c}6 \mu \mathrm{mol} \text { in } 8 \\
\mathrm{~h}\end{array}$ & N/A & {$[66]$} \\
\hline Pillar $\mathrm{TiO}_{2}$ & 2 & $\begin{array}{c}0.5 \mathrm{M} \mathrm{H}_{2} \mathrm{SO}_{4} / \\
1 \mathrm{M} \mathrm{NaOH}\end{array}$ & $\begin{array}{c}\text { UV light with } \\
\text { intensity of } 25 \\
\mathrm{~mW} / \mathrm{cm}^{2}\end{array}$ & $\begin{array}{c}37 \mu \mathrm{mol} \text { in } \\
8 \mathrm{~h}\end{array}$ & N/A & {$[67]$} \\
\hline $\mathrm{WSe}_{2}$ & 0.0125 & $\begin{array}{c}1 \mathrm{M} \mathrm{KI}+0.05 \\
\mathrm{M} \mathrm{I}_{2}\end{array}$ & $\begin{array}{c}60 \mathrm{~mW} / \mathrm{cm}^{2} \\
\text { tungsten lamp }\end{array}$ & $\begin{array}{c}\mathrm{ABPE}= \\
17.1 \%\end{array}$ & N/A & [71] \\
\hline $\begin{array}{c}\mathrm{p}-\mathrm{GaAs} / n-\mathrm{GaAs} / \\
\mathrm{p}-\mathrm{GaInP}_{2}\end{array}$ & 0.2 & $3 \mathrm{M} \mathrm{H}_{2} \mathrm{SO}_{4}$ & $\begin{array}{c}150 \mathrm{~W} \\
\text { tungsten-halogen } \\
\text { lamp } \\
\end{array}$ & $\begin{array}{c}\mathrm{ABPE}= \\
12.4 \%\end{array}$ & 0.3 & [73] \\
\hline $\mathrm{GaInP}_{2} / \mathrm{GaAs}$ & 0.5 & $2 \mathrm{M} \mathrm{KOH}$ & 75 W Xe lamp & $\begin{array}{c}\mathrm{ABPE}= \\
16.5 \%\end{array}$ & N/A & {$[75]$} \\
\hline Triple a-Si & 0.3 & $2 \mathrm{M} \mathrm{KOH}$ & 75 W Xe lamp & $\begin{array}{c}\mathrm{ABPE}= \\
7.8 \%\end{array}$ & N/A & {$[75]$} \\
\hline $\mathrm{AlGaAs} / \mathrm{Si}$ & 0.22 & $1 \mathrm{M} \mathrm{HClO}_{4}$ & $\begin{array}{c}50 \mathrm{~W} \\
\text { tungsten-halogen } \\
\text { lamp }\end{array}$ & $\begin{array}{c}\mathrm{ABPE}= \\
18.3 \%\end{array}$ & N/A & {$[77]$} \\
\hline $\mathrm{InGaP} / \mathrm{GaAs} / \mathrm{Ge}$ & 2 & $\begin{array}{c}0.5 \mathrm{M} \mathrm{H}_{2} \mathrm{SO}_{4} / \\
1 \mathrm{M} \mathrm{NaOH}\end{array}$ & AM 1.5 & $\begin{array}{c}440 \mu \mathrm{mol} \\
\text { in } 8 \mathrm{~h}\end{array}$ & N/A & {$[78]$} \\
\hline
\end{tabular}


Table 2. Cont.

\begin{tabular}{|c|c|c|c|c|c|c|}
\hline Photoelectrode & $\begin{array}{c}\text { Surface } \\
\text { area }\left(\mathbf{c m}^{\mathbf{2}}\right)\end{array}$ & Electrolyte & Light source & $\begin{array}{c}\text { Efficiency/ } \\
\mathbf{H}_{\mathbf{2}} \text { yield }\end{array}$ & $\begin{array}{c}\text { Applied } \\
\text { bias (V) }\end{array}$ & Reference \\
\hline $\mathrm{CM} n-\mathrm{TiO}_{2}$ & 0.2 & $5 \mathrm{M} \mathrm{KOH}$ & $150 \mathrm{~W}$ Xe lamp & $\begin{array}{c}\mathrm{ABPE}= \\
8.35 \%\end{array}$ & 0.3 & {$[18]$} \\
\hline$n-\mathrm{TiO}_{2}$ & 0.2 & $5 \mathrm{M} \mathrm{KOH}$ & $150 \mathrm{~W}$ Xe lamp & $\begin{array}{c}\mathrm{ABPE}= \\
1.08 \%\end{array}$ & 0.6 & {$[18]$} \\
\hline
\end{tabular}

\section{Current Challenges and Future Prospects of Photocatalytic Water Splitting}

Over the past few decades, several semiconductor materials and photocatalytic systems have been developed for the water-splitting reaction under UV and visible-light irradiation. It has been observed that photo-generated charge separation, prevention of water-splitting backward reaction, and utilization of a large fraction of the incident energy are the essential requirements for achieving high photo-conversion efficiency. Enhanced hydrogen production has been shown by the addition of hole scavengers or sacrificial agents that irreversibly react with the VB holes to inhibit charge recombination. However, to attain sustainable hydrogen production, sacrificial agents must be continuously added. Moreover, the design of novel photocatalytic reactor systems to achieve separate $\mathrm{H}_{2}$ and $\mathrm{O}_{2}$ evolution, such as the H-type reactor and the novel Z-scheme, have also shown enhanced hydrogen production by preventing the backward reaction of water splitting. Various syntheses procedures, such as loading and/or doping of metal or metal oxide particles on the photocatalyst, and the preparation of dye-sensitized or composite photocatalysts have been successfully employed to improve the performance of photocatalytic water splitting. These methods are effective in terms of tuning the bandgap of material for harnessing a greater portion of visible light, as well as preventing charge recombination. In addition, numerous non-oxide semiconductor materials have shown improved performances for photocatalytic water splitting. However, the stability of the materials remains a major challenge for their application.

In summary, photocatalytic water splitting is a cross-discipline technology that requires the involvement of experts from different fields (i.e., chemists, electrical engineers, material scientists, and physicists). A joint effort is needed to explore potential semiconductor materials and reactor systems that will generate the highest solar-to-hydrogen efficiency. The development of new technologies requires collaboration with a strong theoretical background for a better understanding of the hydrogen production mechanism in order to come up with a low-cost and environmentally friendly water-splitting process for hydrogen production.

\section{References}

1. Solomon, S.; Plattner, G.K.; Knutti, R.; Friedlingstein, P. Irreversible climate change due to carbon dioxide emissions. Proc. Natl. Acad. Sc. USA 2009, 106, 1704-1709.

2. Primio, R.D.; Horsfield, B.; Guzman-Vega, M.A. Determining the temperature of petroleum formation from the kinetic properties of petroleum asphaltenes. Nature 2000, 406, 173-176.

3. Chiari, L.; Zecca, A. Constraints of fossil fuels depletion on global warming projections. Energy Policy 2011, 39, 5026-5034. 
4. Dincer, F. The analysis on wind energy electricity generation status, potential and policies in the world. Renew. Sustain. Energy Rev. 2011, 15, 5135-5142.

5. Yuksel, I. Hydropower for sustainable water and energy development. Renew. Sustain. Energy Rev. 2010, 14, 462-469.

6. Parida, B.; Iniyan, S.; Goic, R. A review of solar photovoltaic technologies. Renew. Sustain. Energy Rev. 2011, 15, 1625-1636.

7. Xie, W.T.; Dai, Y.J.; Wang, R.Z.; Sumathy, K. Concentrated solar energy applications using Fresnel lenses: A review. Renew. Sustain. Energy Rev. 2011, 15, 2588-2606.

8. Barbier, E. Geothermal energy technology and current status: an overview. Renew. Sustain. Energy Rev.2002, 6, 3-65.

9. Midilli, A.; Ay, M.; Dincer, I.; Rosen, M.A. On hydrogen and hydrogen energy strategies I: Current status and needs. Renew. Sustain. Energy Rev. 2005, 9, 255-271.

10. Hou, K.H.; Hughes, R. The kinetics of methane steam reforming over a Ni/alpha- $\mathrm{Al}_{2} \mathrm{O}$ catalyst. Chem. Eng. J. 2001, 82, 311-328.

11. Nowotny, J.; Sorrell, C.C.; Sheppard, L.R.; Bak, T. Solar-hydrogen: Environmentally safe fuel for the future. Int. J. Hydrog. Energy 2005, 30, 521-544.

12. Czernik, S.; Evans, R.; French, R. Hydrogen from biomass-production by steam reforming of biomass pyrolysis oil. Catal. Today 2007 129, 265-268.

13. Ni, M.; Leung, D.Y.C.; Leung, M.K.H.; Sumathy, K. An overview of hydrogen production from biomass. Fuel Process. Tech. 2006, 87, 461-472.

14. Steinfeld, A. Solar hydrogen production via a two-step water-splitting thermochemical cycle based on $\mathrm{Zn} / \mathrm{ZnO}$ redox reactions. Int. J. Hydrog. Energy 2002, 27, 611-619.

15. Akkerman, I.; Janssen, M.; Rocha, J.; Wijffels, R.H. Photobiological hydrogen production: photochemical efficiency and bioreactor design. Int. J. Hydrog. Energy 2002, 27, 1195-1208.

16. Das, D.; Veziroglu, T.N. Advances in biological hydrogen production processes. Int. J. Hydrog. Energy 2008, 33, 6046-6057.

17. Guan, Y.F.; Deng, M.C.; Yu, X.J.; Zhang, W. Two-stage photo-biological production of hydrogen by marine green alga Platymonas subcordiformis. Biochem. Eng. J. 2004, 19, 69-73.

18. Khan, S.U.M.; Al-Shahry, M.; Ingler, W.B. Efficient photochemical water splitting by a chemically modified $n-\mathrm{TiO}_{2}$. Science 2002, 297, 2243-2245.

19. Bak, T.; Nowotny, J.; Rekas, M.; Sorrell, C.C. Photo-electrochemical hydrogen generation from water using solar energy. Materials-related aspects. Int. J. Hydrog. Energy 2002, 27, 991-1022.

20. Chen, Z.B.; Jaramillo, T.F.; Deutsch, T.G.; Kleiman-Shwarsctein, A.; Forman, A.J.; Gaillard, N.; Garland, R.; Takanabe, K.; Heske, C.; Sunkara, M.; et al. Accelerating materials development for photoelectrochemical hydrogen production: Standards for methods, definitions, and reporting protocols. J. Mater. Res. 2010, 25, 3-16.

21. Kudo, A.; Miseki, Y. Heterogeneous photocatalyst materials for water splitting. Chem. Soc. Rev. 2009, 38, 253-278. 
22. Li, Y.X.; Lu, G.X.; Li, S.B. Photocatalytic production of hydrogen in single component and mixture systems of electron donors and monitoring adsorption of donors by in situ infrared spectroscopy. Chemosphere 2003, 52, 843-850.

23. Sayama, K.; Arakawa, H. Effect of carbonate salt addition on the photocatalytic decomposition of liquid water over Pt-TiO 2 catalyst. J. Chem. Soc.-Faraday Trans. 1997, 93, 1647-1654.

24. Sayama, K.; Arakawa, H. Photocatalytic decomposition of water and photocatalytic reduction of carbon-dioxide over $\mathrm{ZrO}_{2}$ catalyst. J.Phys. Chem. 1993, 97, 531-533.

25. Subramanian, V.; Wolf, E.E.; Kamat, P.V. Catalysis with $\mathrm{TiO}_{2} /$ gold nanocomposites. Effect of metal particle size on the Fermi level equilibration. J. Am. Chem. Soc. 2004, 126, 4943-4950.

26. Bamwenda, G.R.; Tsubota, S.; Nakamura, T.; Haruta, M. Photoassisted hydrogen production from a water-ethanol solution: a comparison of activities of $\mathrm{Au}-\mathrm{TiO}_{2}$ and $\mathrm{Pt}-\mathrm{TiO}_{2}$. J. Photochem. Photobiol. A 1995, 89, 177-189.

27. Murdoch, M.; Waterhouse, G.I.N.; Nadeem, M.A.; Metson, J.B.; Keane, M.A.; Howe, R.F.; Llorca, J.; Idriss, H. The effect of gold loading and particle size on photocatalytic hydrogen production from ethanol over $\mathrm{Au} / \mathrm{TiO}_{2}$ nanoparticles. Nature Chem. 2011, 3, 489-492.

28. Anpo, M.; Takeuchi, M. The design and development of highly reactive titanium oxide photocatalysts operating under visible light irradiation. J. Catal. 2003, 216, 505-516.

29. Merlen, A.; Gadenne, V.; Romann, J.; Chevallier, V.; Patrone, L.; Valmalette, J.C. Surface enhanced Raman spectroscopy of organic molecules deposited on gold sputtered substrates. Nanotechnology 2009, 20, doi:10.1088/0957-4484/20/21/215705.

30. Primo, A.; Corma, A.; Garcia, H. Titania supported gold nanoparticles as photocatalyst. Phys. Chem. Chem. Phys. 2011, 13, 886-910.

31. Primo, A.; Marino, T.; Corma, A.; Molinari, R.; Garcia, H. Efficient Visible-Light Photocatalytic Water Splitting by Minute Amounts of Gold Supported on Nanoparticulate $\mathrm{CeO}_{2}$ Obtained by a Biopolymer Templating Method. J. Am. Chem. Soc. 2012, 133, 6930-6933.

32. Awazu, K.; Fujimaki, M.; Rockstuhl, C.; Tominaga, J.; Murakami, H.; Ohki, Y.; Yoshida, N.; Watanabe, T. A plasmonic photocatalyst consisting of sliver nanoparticles embedded in titanium dioxide. J. Am. Chem. Soc. 2008, 130, 1676-1680.

33. Kowalska, E.; Abe, R.; Ohtani, B. Visible light-induced photocatalytic reaction of gold-modified titanium(IV) oxide particles: Action spectrum analysis. Chem. Commun. 2009, doi:10.1039/B815679D.

34. Silva, C.G.; Juarez, R.; Marino, T.; Molinari, R.; Garcia, H. Influence of Excitation Wavelength (UV or Visible Light) on the Photocatalytic Activity of Titania Containing Gold Nanoparticles for the Generation of Hydrogen or Oxygen from Water. J. Am. Chem. Soc. 2011, 133, 595-602.

35. Gurunathan, K.; Maruthamuthu, P.; Sastri, M.V.C. Photocatalytic hydrogen production by dye-sensitized $\mathrm{Pt} / \mathrm{SnO}_{2} \mathrm{AND} \mathrm{Pt} / \mathrm{SnO}_{2} / \mathrm{RuO}_{2}$ in aqueous methyl viologen solution. Int. J. Hyd. Energy 1997, 22, 57-62. 
36. Ni, M.; Leung, M.K.H.; Leung, D.Y.C.; Sumathy, K. A review and recent developments in photocatalytic water-splitting using $\mathrm{TiO}_{2}$ for hydrogen production. Renew. Sustain. Energy Rev. 2007, 11,401-425.

37. Jing, D.; Guo, L. $\mathrm{WS}_{2}$ sensitized mesoporous $\mathrm{TiO}_{2}$ for efficient photocatalytic hydrogen production from water under visible light irradiation. Catal. Commun. 2007, 8, 795-799.

38. Sauve, G.; Cass, M.E.; Coia, G.; Doig, S.J.; Lauermann, I.; Pomykal, K.E.; Lewis, N.S. Dye sensitization of nanocrystalline titanium dioxide with osmium and ruthenium polypyridyl complexes. J. Phys. Chem. B 2000, 104, 6821-6836.

39. Chen, Y.S.; Li, C.; Zeng, Z.H.; Wang, W.B.; Wang, X.S.; Zhang, B.W. Efficient electron injection due to a special adsorbing group's combination of carboxyl and hydroxyl: dye-sensitized solar cells based on new hemicyanine dyes. J. Mater. Chem. 2005, 15, 1654-1661.

40. Chen, C.P.; Qi, X.Y.; Zhou, B.M. Photosensitization of colloidal $\mathrm{TiO}_{2}$ with a cyanine dye. $J$. Photochem. Photobiol.1997, 109, 155-158.

41. Chu, W.; Chan, K.H.; Jafvert, C.T.; Chan, Y.S. Removal of phenylurea herbicide monuron via riboflavin-mediated photo sensitization. Chemosphere 2007, 69, 177-183.

42. Choi, W.; Termin, A.; Hoffmann, M.R. The Role of Metal Ion Dopants in Quantum-Sized $\mathrm{TiO}_{2}$ : Correlation between Photoreactivity and Charge Carrier Recombination Dynamics. J. Phys. Chem. 1994, 98, 13669-13679.

43. Litter, M.I. Heterogeneous photocatalysis: Transition metal ions in photocatalytic systems. Appl. Cataly. B 1999, 23, 89-114.

44. Asahi, R.; Morikawa, T.; Ohwaki, T.; Aoki, K.; Taga, Y. Visible-light photocatalysis in nitrogen-doped titanium oxides. Science 2001, 293, 269-271.

45. Abe, R.; Takata, T.; Sugihara, H.; Domen, K. Photocatalytic overall water splitting under visible light by $\mathrm{TaON}$ and $\mathrm{WO}_{3}$ with an $\mathrm{IO}_{3}{ }^{-} / \mathrm{I}^{-}$shuttle redox mediator. Chem. Commun. 2005, 38, 29-3831.

46. Kobayakawa, K.; Murakami, Y.; Sato, Y. Visible-light active N-doped $\mathrm{TiO}_{2}$ prepared by heating of titanium hydroxide and urea. J. Photochem. Photobiol. A 2005, 170, 177-179.

47. Mrowetz, M.; Balcerski, W.; Colussi, A.J.; Hoffmann, M.R. Oxidative power of nitrogen-doped $\mathrm{TiO}_{2}$ photocatalysts under visible illumination. J. Phys. Chem. B 2004, 108, 17269-17273.

48. Torres, G.R.; Lindgren, T.; Lu, J.; Granqvist, C.-G.; Lindquist, S.-E. Photoelectrochemical Study of Nitrogen-Doped Titanium Dioxide for Water Oxidation. J. Phys. Chem. B 2004, 108, 5995-6003.

49. Domen, K.; Kudo, A.; Onishi, T.; Kosugi, N.; Kuroda, H. Photocatalytic decomposition of water into hydrogen and oxygen over nickel(II) oxide-strontium titanate $\left(\mathrm{SrTiO}_{3}\right)$ powder. 1. Structure of the catalysts. J. Phys. Chem. 1986, 90, 292-295.

50. Kudo, A.; Kato, H.; Nakagawa, S. Water Splitting into $\mathrm{H}_{2}$ and $\mathrm{O}_{2}$ on $\mathrm{New} \mathrm{Sr}_{2} \mathrm{M}_{2} \mathrm{O}_{7}(\mathrm{M}=\mathrm{Nb}$ and Ta) Photocatalysts with Layered Perovskite Structures: Factors Affecting the Photocatalytic Activity. J. Phys. Chem. B 1999, 104, 571-575. 
51. Kato, H.; Kudo, A. New tantalate photocatalysts for water decomposition into $\mathrm{H}_{2}$ and $\mathrm{O}_{2}$. Chem. Phys. Lett. 1998, 295, 487-492.

52. Sato, J.; Saito, N.; Nishiyama, H.; Inoue, Y. Photocatalytic Activity for Water Decomposition of Indates with Octahedrally Coordinated d10 Configuration. I. Influences of Preparation Conditions on Activity. J. Phys. Chem. B 2003, 107, 7965-7969.

53. Sayama, K.; Arakawa, H.; Domen, K. Photocatalytic water splitting on nickel intercalated $\mathrm{A}\left({ }_{4}\right) \mathrm{Ta}\left({ }_{x}\right) \mathrm{Nb}_{(6-x)} \mathrm{O}_{(17)}(\mathrm{A}=\mathrm{K}, \mathrm{Rb})$. Cataly. Today 1996, 28, 175-182.

54. Yamada, S.; Nosaka, A.Y.; Nosaka, Y. Fabrication of US photoelectrodes coated with titania nanosheets for water splitting with visible light. J. Electroanal. Chem. 2005, 585, 105-112.

55. Gopidas, K.R.; Bohorquez, M.; Kamat, P.V. Photophysical and photochemical aspects of coupled semiconductors: Charge-transfer processes in colloidal cadmium sulfide-titania and cadmium sulfide-silver(I) iodide systems. J. Phy. Chem. 1990, 94, 6435-6440.

56. Sasaki, Y.; Iwase, A.; Kato, H.; Kudo, A. The effect of co-catalyst for Z-scheme photocatalysis systems with an $\mathrm{Fe}^{3+} / \mathrm{Fe}^{2+}$ electron mediator on overall water splitting under visible light irradiation. J. Catal. 2008, 259, 133-137.

57. Fujihara, K.; Ohno, T.; Matsumura, M. Splitting of water by electrochemical combination of two photocatalytic reactions on $\mathrm{TiO}_{2}$ particles. J. Chem. Soci. Faraday Trans. 1998, 94, 3705-3709.

58. Sayama, K.; Mukasa, K.; Abe, R.; Abe, Y.; Arakawa, H. A new photocatalytic water splitting system under visible light irradiation mimicking a Z-scheme mechanism in photosynthesis. J.Photochem. Photobiol. 2002, 148, 71-77.

59. Higashi, M.; Abe, R.; Takata, T.; Domen, K. Photocatalytic Overall Water Splitting under Visible Light Using $\mathrm{ATaO}_{2} \mathrm{~N}(\mathrm{~A}=\mathrm{Ca}, \mathrm{Sr}, \mathrm{Ba})$ and $\mathrm{WO} 3$ in a $\mathrm{IO}_{3}{ }^{-} / \mathrm{I}^{-}$Shuttle Redox Mediated System. Chem.Mater. 2009, 21, 1543-1549.

60. Kato, H.; Hori, M.; Konta, R.; Shimodaira, Y.; Kudo, A. Construction of Z-scheme Type Heterogeneous Photocatalysis Systems for Water Splitting into $\mathrm{H}_{2}$ and $\mathrm{O}_{2}$ under Visible Light Irradiation. Chem. Lett. 2004, 33, 1348-1349.

61. Fujishima, A.; Honda, K. Electrochemical Photolysis of Water at a Semiconductor Electrode. Nature 1972, 238, 37-38.

62. Wrighton, M.S.; Ellis, A.B.; Wolczanski, P.T.; Morse, D.L.; Abrahamson, H.B.; Ginley, D.S. Strontium-titanate photoelectrodes-efficient photoassisted electrolysis of water at zero applied potential. J. Am. Chem. Soc. 1976, 98, 2774-2779.

63. Ki, H.Y.; Tae, H.K. Photoeffects in undoped and doped $\mathrm{SrTiO}_{3}$ ceramic electrodes. J. Solid State Chem. 1987, 67, 359-363.

64. Matsuoka, M.; Kitano, M.; Takeuchi, M.; Tsujimaru, K.; Anpo, M.; Thomas, J.M. Photocatalysis for new energy production: Recent advances in photocatalytic water splitting reactions for hydrogen production. Catal. Today 2007, 122, 51-61.

65. Huang, C.W.; Liao, C.H.;Wu, J.C.S.; Liu, Y.C.; Chang, C.L.; Wu, C.H.; Anpo, M.; Matsuoka, M.; Takeuchi, M. Hydrogen generation from photocatalytic water splitting over $\mathrm{TiO}_{2}$ thin film prepared by electron beam-induced deposition. Int. J. Hydrog. Energy 2010, 35, 12005-12010. 
66. Liao, C.-H.; Huang, C.-W.; Wu, J.C.S. Novel dual-layer photoelectrode prepared by RF magnetron sputtering for photocatalytic water splitting. Int. J. Hydrog. Energy 2012, 37, $11632-11639$.

67. Liao, Y.-T.; Huang, C.-W.; Liao, C.-H.; Wu, J.C.S.; Wu, K.C.W. Synthesis of mesoporous titania thin films (MTTFs) with two different structures as photocatalysts for generating hydrogen from water splitting. Appl. Energy 2012, doi: 10.1016/j.apenergy.2012.02.053.

68. Matsuoka, M.; Kitano, M.; Fukumoto, S.; Iyatani, K.; Takeuchi, M.; Anpo, M. The effect of the hydrothermal treatment with aqueous $\mathrm{NaOH}$ solution on the photocatalytic and photoelectrochemical properties of visible light-responsive $\mathrm{TiO}_{2}$ thin films. Catal. Today 2008, 132, 159-164.

69. Lo, C.-C.; Huang, C.-W.; Liao, C.-H.; Wu, J.C.S. Novel twin reactor for separate evolution of hydrogen and oxygen in photocatalytic water splitting. Int. J. Hydrog. Energy 2010, 35, 1523-1529.

70. Yu, S.C.; Huang, C.W.; Liao, C.H.; Wu, J.C.S.; Chang, S.T.; Chen, K.H. A novel membrane reactor for separating hydrogen and oxygen in photocatalytic water splitting. J. Membr. Sci.2011, 382, 291-299.

71. Prasad, G.; Chandra Babu, K.S.; Srivastava, O.N. Structural and photoelectrochemical studies of $\mathrm{In}_{2} \mathrm{O}_{3}-\mathrm{TiO}_{2}$ and $\mathrm{WSe}_{2}$ photoelectrodes for photoelectrochemical production of hydrogen. Int. J. Hydrog. Energy 1989, 14, 537-544.

72. Licht, S.; Wang, B.; Mukerji, S.; Soga, T.; Umeno, M.; Tributsch, H. Over 18\% solar energy conversion to generation of hydrogen fuel; theory and experiment for efficient solar water splitting. Int. J. Hydrog. Energy 2001, 26, 653-659.

73. Khaselev, O.; Turner, J.A. A monolithic photovoltaic-photoelectrochemical device for hydrogen production via water splitting. Science 1998,280, 425-427.

74. Peharz, G.; Dimroth, F.; Wittstadt, U. Solar hydrogen production by water splitting with a conversion efficiency of 18\%. Int. J. Hydrog. Energy 2007, 32, 3248-3252.

75. Khaselev, O.; Bansal, A.; Turner, J.A. High-efficiency integrated multijunction photovoltaic/electrolysis systems for hydrogen production. Int. J. Hydrog. Energy 2001, 26, 127-132.

76. Miller, E.L.; Rocheleau, R.E.; Khan, S. A hybrid multijunction photoelectrode for hydrogen production fabricated with amorphous silicon/germanium and iron oxide thin films. Int. J. Hydrog. Energy 2004, 29, 907-914.

77. Licht, S.; Wang, B.; Mukerji, S.; Soga, T.; Umeno, M.; Tributsch, H. Efficient solar water splitting, exemplified by $\mathrm{RuO}_{2}$-catalyzed AlGaAs/Si photoelectrolysis. J. Phys. Chem. B 2000, 104, 8920-8924. 
78. Huang, C.-W.; Liao, C.-H.; Wu, C.-H.; Wu, J.C.S. Photocatalytic water splitting to produce hydrogen using multi-junction solar cell with different deposited thin films. Sol. Energy Mater. Sol. Cells 2012, doi: 10.1016/j.solmat.2012.07.003.

(C) 2012 by the authors; licensee MDPI, Basel, Switzerland. This article is an open access article distributed under the terms and conditions of the Creative Commons Attribution license (http://creativecommons.org/licenses/by/3.0/). 